\title{
Apatite Composition and U-Pb Geochronology from the Ptarmigan and Tom Deposits, NWT Canada; Implications for Petrogenesis
}

\author{
Mark W. Richardson $^{1 *}$, Christopher R.M. McFarlane' ${ }^{1}$, David R. Lentz ${ }^{1}$, Hendrik Falck ${ }^{2}$ \\ ${ }^{1}$ Department of Earth Sciences, University of New Brunswick, P.O. Box 4400, Fredericton, NB E3B 5A3, Canada \\ 2Department of Industry, Tourism and Investment, Government of the Northwest Territories, \\ Scotia Centre 4th Floor, 5102 50 th Avenue, Yellowknife NT X1A 2L9 Canada \\ *Correspondence: m5b11@unb.ca (M.W.R) \\ dlentz@unb.ca (D.R.L.); crmm@unb.ca (C.R.M.M.); Hendrik_Falck@gov.nt.ca (H.F)
}

\begin{abstract}
:
The Ptarmigan and Tom mesothermal gold deposits are located $10 \mathrm{~km}$ to the northeast of the city of Yellowknife, Northwest Territories in northern Canada. Both gold deposits comprise a series of en echelon veins that are hosted within upper greenschist to lower amphibolite facies $\sim 2630 \mathrm{Ma}$ (peak) rocks. Supracrustal units across the craton are intruded by the ca. 2610-2605-Ma granodiorite, tonalite, monzodiorite, quartz diorite, and affiliated rocks of the Concession Suite. Hydrothermal apatite is a common accessory mineral in both mineralized and non-mineralized quartz veins in the metasedimentary host rocks that constitute the Ptarmigan and Tom deposits. This study characterizes and compares turbidite-hosted hydrothermal apatite from the Ptarmigan and Tom deposits, nonmineralized veins adjacent to the ore body, and magmatic apatite from proximal LCT-pegmatites. Using electron probe microanalyses (EPMA), laser ablation inductively coupled plasma-mass spectrometry (LA-ICP-MS), micro-XRF, and cathodoluminescence (CL), the major, minor, and trace element abundances have been quantified and mapped. In addition to utilizing this data to determine if the chemistry of apatite can be used to constrain the source of hydrothermal fluids, the apparent age of the apatite is also evaluated utilizing in situ $\mathrm{U}-\mathrm{Pb}$ dating.

The distribution and abundance of major, minor, and trace elements from in situ recovered apatite were studied to characterize the nature of mineralizing fluids. Most apatite from mineralized and non-mineralized veins show different $\mathrm{Mn}, \mathrm{Sr}$, and $\mathrm{Pb}$ contents, as well as chondrite-normalized rare-earth element (REE) and Y abundance patterns. REEs display five unique chondrite-normalized patterns: (1) negative sloped pattern with slight negative Eu anomaly, (2) a flat pattern with a positive Eu anomaly, (3) a positive slope with a negative Eu anomaly, (iv) light rare earth element (LREE) depleted pattern with positive Eu anomaly, and (v) bell-shaped pattern with a negative Eu anomaly. The REE patterns reflect both the source of the auriferous hydrothermal fluids and, perhaps, coprecipitating mineral phases. Apatite from the Ptarmigan vein occurs with both: (1) a flat pattern with a positive Eu anomaly and (2) bell-shaped pattern with a negative Eu anomaly. The bell-shaped and flat patterns typify orogenic gold deposits. Vein-hosted apatite commonly displays compositional zoning with a characteristic yellow cathodoluminescence (CL) emission spectra with darker cores and brighter rims. The cores have lower REE, whereas the rims are notably higher in REE. It is thought that the darker cores in CL images reflect a transition from an early low REE hydrothermal fluid to one enriched in REE. The hydrothermal apatite age of $2585 \pm 15 \mathrm{Ma}$ is consistent with the intrusions of the 2605 and 2590 Ma two-mica granites of the Prosperous Suite and associated LCT pegmatites.

The near-concordant ${ }^{204} \mathrm{~Pb}$-corrected data of the LCT pegmatite hosted apatite reveals two clusters of ages. An older population with a Concordia age $(n=4)$ of $2581 \pm 15 \mathrm{Ma}$, and a younger population with an age $(n=3)$ of $2519 \pm 12$ Ma . Furthermore, plotting a regression through all near -
\end{abstract}


concordant data for the pegmatite hosted apatite hints that metamorpic resetting occurred around $\sim 2200$ Ma.

Keywords: apatite; rare earth elements; hydrothermal fluids; Ptarmigan Mine;

\section{Introduction}

The Yellowknife Greenstone Belt (hereafter referred to as YGB) in the Northwest Territories, Canada (Figure 1) hosts a variety of gold occurrences including the world-class Con and Giant mines. The lesser-known Ptarmigan and Tom deposits occur $10 \mathrm{~km}$ NW of the city of Yellowknife. The Ptarmigan and Tom gold occurrences consist of en-echelon gold-bearing quartz veins hosted by metasandstones and metasiltstones of the Burwash Formation. Supracrustal units across the craton are intruded by the ca. 2610-2605-Ma granodiorite, tonalite, monzodiorite, quartz diorite, and affiliated rocks of the Concession Suite [1]. The Concession Suite plutons have significantly enriched LREEs, high $\mathrm{K}_{2} \mathrm{O}$, and overall geochemical affinities that are most like those derived from a subduction-enriched lithosphere that began melting because of post collision delamination [1]. Following this, 2600-2580-Ma granite sheets and plutons derived from crustal melts intruded all the Neoarchean rocks, except the late-orogenic conglomerates (e.g., [1-2]). Prosperous granite-associated LCT-pegmatites occur throughout the study area [3].

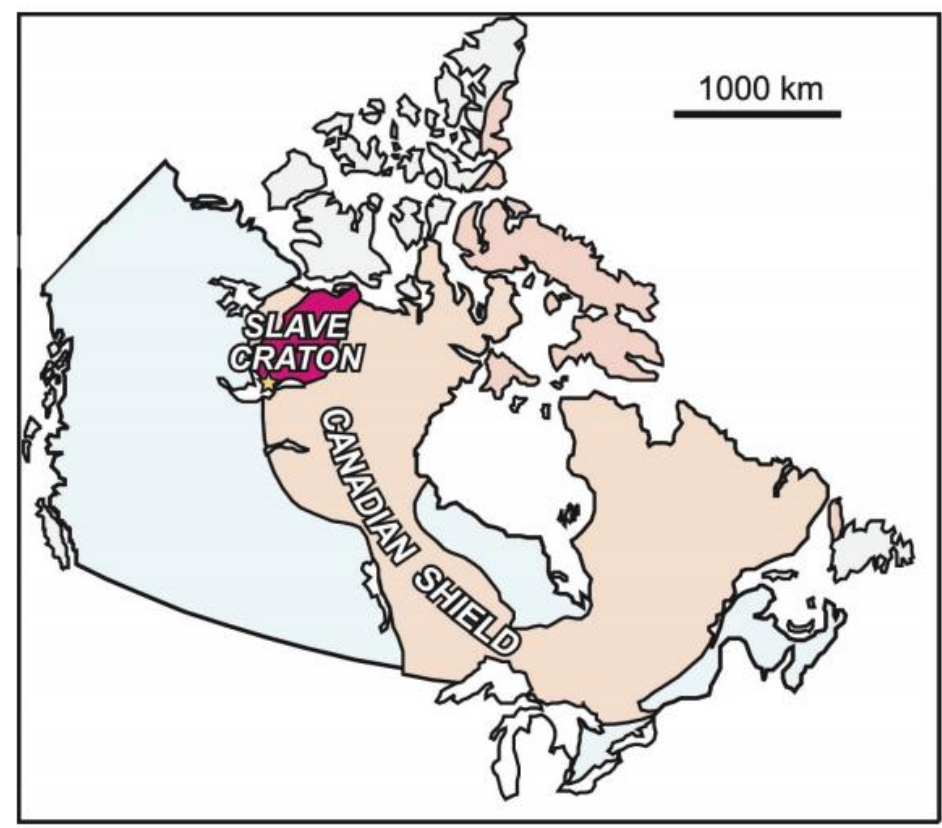

Figure 1: Location of the Slave (Structural) Province in northern Canada (red) and the rest of the Canadian shield (beige). Yellow star indicates the approximate location of the study area (modified after [4]).

Both the margins of the quartz veins and the pegmatites observed at the Ptarmigan and Tom deposits typically have tourmaline-rich rims. Zoning in the pegmatites is simple with a quartz core, an intermediate zone of plagioclase, muscovite, tourmaline, and an outer finer grained zone (cf. [5]). Additionally, M. Seigel [6] found that tourmaline needles from the Prosperous Granite, Ptarmigan Mine, and the Con Mine are likely related. During mapping of Ross Lake area $(25 \mathrm{~km}$ east of Ptarmigan Mine) a continuum between pegmatites and quartz veins was observed [7].

Turbidite-hosted gold deposits occur world-wide (e.g., [8,9]). However, the tectonic setting, timing, and nature of veining and source reservoirs has led to a variety of genetic models (i.e., magmatic versus metamorphic versus meteoric (e.g., $[9,10])$. Rare earth elements and yttrium (REY) 
compositions of accessory hydrothermal minerals have been shown to record the chemical make-up of ore-bearing hydrothermal fluids (i.e., apatite, [11-13]). The geochemical characteristics of hydrothermal fluids may help elucidate key differences between the proposed models.

Apatite $\mathrm{Ca} 5\left(\mathrm{PO}_{4}\right)_{3}(\mathrm{~F}, \mathrm{Cl}, \mathrm{OH})$ is a common calcium phosphate accessory mineral in igneous, sedimentary, and metamorphic rocks, and can also precipitate from hydrothermal fluids [14,15]. Apatite lattice can accommodate several cation substitutions through its ninefold $\mathrm{M}_{1}$ and sevenfold $\mathrm{M}_{2}$ polyhedral sites (also called the $\mathrm{Ca}_{1}$ and $\mathrm{Ca}_{2}$ sites). These substitutions include many divalent and trivalent cations, such as $\mathrm{Na}, \mathrm{Mg}, \mathrm{Mn}, \mathrm{Fe}, \mathrm{Sr}, \mathrm{Y}, \mathrm{Ba}$, lanthanides (rare earth elements hereafter referred to as REE), $\mathrm{Pb}$, Th, and $\mathrm{U}[16,17]$. The variety of substitution possibilities has made apatite highly susceptible to various fluid induced (metasomatic) chemical and textural changes over a wide range of pressures and temperatures [18].

In hydrothermal fluids the apatite four-component system $(\mathrm{Ca}, \mathrm{P}, \mathrm{O}$, and $\mathrm{F})$ can form various aqueous complexes. The phosphate ion has a stepwise association with $\mathrm{H}^{+}$to form the species $\mathrm{H}_{2} \mathrm{PO}_{4}^{-}$, and $\mathrm{H}_{3} \mathrm{PO}_{4}$. Calcium can also form complexes, such as $\mathrm{CaCl}_{2}, \mathrm{CaOH}^{+}, \mathrm{CaPO}_{4}^{-}, \mathrm{CaH}_{2} \mathrm{PO}_{4}^{+}$, and $\mathrm{CaHPO}_{4}$ and lastly, $\mathrm{F}^{-}$may complex with $\mathrm{H}^{+}$to form HF. For example, it has been demonstrated that pressure, temperature, and dissolved silicates have limited influence on the solubility of apatite, whereas lower $\mathrm{pH}$ increases the solubility of apatite [19]. The occurrence of large apatite crystals in hydrothermal veins reflect the increased concentrations of mobile $\mathrm{Ca}, \mathrm{P}, \mathrm{O}$, and $\mathrm{F}$.

Since rare-earth elements (REE) are hard cations, Pearson's rules [20] implies that they will bond preferentially with hard anions, such as $\mathrm{F}-\mathrm{CO}_{3}^{-2}, \mathrm{CO}_{3}^{-2} \mathrm{CO}_{3}^{-2}, \mathrm{P}_{2} \mathrm{O}_{5}^{2-}$, and $\mathrm{SO}_{4}^{2-}$. Therefore, fluids saturated in hard ligands will facilitate greater REE mobility in a hydrothermal solution. Thus, REE abundance in hydrothermal apatite is correlated to saturation of apatite in the vein and the presence of $\mathrm{F}-\mathrm{OH}, \mathrm{CO}_{3}^{-2}, \mathrm{P}_{2} \mathrm{O}_{5}^{2-}$ complexes available. Chloride complexes are typically most effective at mobilization of REE [21]. Additionally, they demonstrated that the interaction of saline hydrothermal fluid with primary magmatic accessory minerals enriched in REE will preferentially mobilize LREEs [21].

Trace element substitutions in natural apatites can be high; for example, $\mathrm{Sr}$ and $\mathrm{Mn}$ can substitute up to 8.96 and $7.59 \mathrm{wt} . \%$, respectively [22]. The abundance of trace element substitution is dependent on many factors. For example, $\mathrm{Mn}^{2+}$ was observed to substitutes into apatite more readily than $\mathrm{Mn}^{3+}$, so it was concluded that redox conditions have significant influence on the partitioning of $\mathrm{Mn}$ into apatite [23].

Apatite geochemistry (i.e., trace element abundances) has also been used to discriminate between different types of ore deposits [11] and to identify any influence that the host-rock in an oreforming environment has on the composition of apatite [24]. It was also found that REE composition of apatite [16] can be used to provide information regarding the characteristics of fluids responsible for metasomatism as they record the nature of melts and fluids from which apatite saturates. Cathodoluminescence (CL) imaging is a particularly effective tool at observing compositional zonation in apatite. CL utilizes an electron beam that initiates inelastic scattering of primary electrons in the crystal lattice. This results in an emission of secondary electrons that lead to a cascade of scattering of more primary electrons. These secondary electrons may excite the valence electrons from the conduction band which recombine with the valence band and creates a photon. $\mathrm{Mn}^{2+}$ and REE ions are particularly effective at generating secondary electrons during interaction with an electron beam [25]. The compositional zoning can be further verified via elemental-distribution maps, e.g., micro-XRF elemental maps. Trace element zonation observed in hydrothermal apatite may be used to track fluid composition [26] and possibly aid mineral exploration [11].

In addition to metasomatic susceptibility, apatite is also a powerful geochronometer. For example, as new growth of apatite occurs in response to metasomatic processes, the U-Pb geochronometer will record the time at which slowing $\mathrm{Pb}$ diffusion leads to quantitative accumulation of radiogenic $\mathrm{Pb}\left(\mathrm{Pb}^{*}\right)$. If metasomatism induces partial to complete loss of radiogenic$\mathrm{Pb}$ (and (or) $\mathrm{U}$ ) along with changes in trace-element composition, subsequent $\mathrm{U}-\mathrm{Pb}$ dating will record the time of metasomatism. $\mathrm{Th}^{4+}$ and $\mathrm{U}^{4+}$ are the primary tetravalent cations (other than $\mathrm{Si}$ ) found in apatite (few ppm to thousands of ppm) $[11,16,22]$ and high initial concentrations facilitates apatite $\mathrm{U}-\mathrm{Pb}$ geochronology, e.g., [27-30]. However, the precision of $\mathrm{U}-\mathrm{Pb}$ apatite geochronology is lower 
compared to other minerals with high initial $\mathrm{U} / \mathrm{Pb}$, because apatite incorporates a substantial amount of common- $\mathrm{Pb}$ compared to $\mathrm{U}$ when it crystallizes. This leads to moderate to low ratios of ${ }^{238} \mathrm{U} /{ }^{204} \mathrm{~Pb}$ [27]. The high ratio of common to radiogenic $\mathrm{Pb}\left(\mathrm{Pb} / \mathrm{Pb}^{*}\right)$ presents challenges for apatite U-Pb geochronology and calculated dates (cf. [30]). Although precision on individual analyses can be low, the final age of a regression or concordant cluster can be very good. In natural apatite, the $\mathrm{Pb}$ diffusion closure temperature estimates range between $375^{\circ}$ to $600^{\circ} \mathrm{C}$ [26-29], therefore is useful for mid-range cooling ages typical of magmatic-hydrothermal processes.

This study characterizes and compares turbidite-hosted hydrothermal apatite from the Ptarmigan deposit, non-mineralized veins adjacent to the ore body, and magmatic apatite from proximal LCT-pegmatites. Using electron probe microanalysis (EPMA) and laser ablation inductively coupled plasma-mass spectrometry (LA-ICP-MS), micro-XRF, and cathodoluminescence (CL), the major, minor, and trace element abundances have been quantified and mapped. In addition to utilizing this data to determine if the chemistry of apatite can be used to constrain the source of hydrothermal fluids, the apparent age of the apatite is also evaluated utilizing $\mathrm{U}-\mathrm{Pb}$ dating.

\section{Materials and Methods}

Polished $(\sim 30 \mu \mathrm{m})$ thin sections were cut from samples collected from 50 quartz veins in surface outcrops. These samples were selected from mineralized veins, including the wall rocks immediately adjacent to the veins. Petrographic observations were also made on a $35 \times 15 \mathrm{~cm}$ cut slab that spanned the entire width of the Ptarmigan vein in a trench located $~ 350 \mathrm{~m}$ NW of the Ptarmigan Mine shaft (Figure 2). Of the 60 samples taken, 16 contained enough apatite for use in this study.

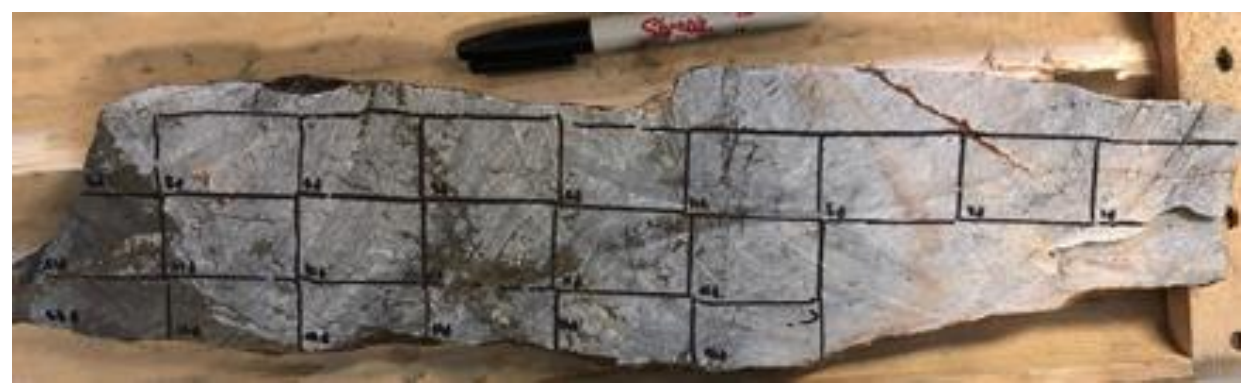

Figure 2: Sample showing the full span of the Ptarmigan vein (pen for scale).

Mineral identification, textural analysis, and imaging were carried out using a petrographic microscope in both transmitted and reflected light on polished thin $(\sim 30 \mu \mathrm{m})$ sections. Apatite grains were imaged with cathodoluminescence (CL) using a Nuclide Corporation Luminoscope coldcathode luminescence stage microscope. Micro-XRF EDS maps were completed at the University of New Brunswick utilizing a Bruker M4 Tornado with Rh X-ray tube with polycapillary focusing to 20 $\mu \mathrm{m}$, dual SDD detectors (130-140 eV resolution). In situ apatite geochronology was completed at the University of New Brunswick via laser ablation-inductively coupled plasma-mass spectrometry (LAICP-MS) using a Resonetics M-50-LR Ar-F 193 nm Excimer laser ablation system coupled to an Agilent 7700 quadrupole ICP-MS. The trace element and U-Pb data was collected simultaneously using laser fluence of $5 \mathrm{~J} / \mathrm{cm}^{2}, 3 \mathrm{~Hz}$ (pulses per second), 60 second ablation time and analyzed with a beam diameter of $60 \mu \mathrm{m}$. Since both U-Pb and trace element data were collected simultaneously three standard reference materials standards were used. The MAD apatite standard (REF) was used as a calibration standard with accuracy checked using an in-house apatite from Phalaborwa, South African (assumed age of $2060 \mathrm{Ma}$ ) NIST610 glass was used as a primary standard for trace element analysis with an assumed stoichiometric value of $39 \mathrm{wt} \% \mathrm{Ca}$ as internal standard. Non-apatite mineral phases were filtered during offline data reduction based on anomalous $\mathrm{Ca}$, trace-element intensities in the ablation time-series, and silicate contamination. Before analysis, targeted apatite grains were visually inspected to be free of mineral inclusions. After measurements were obtained, signal versus time intensity graphs of the raw data were scrutinized for possible contamination by inclusions. Of note, apatite grains from several of the samples were beam sensitive, such that some 
grains were extensively damaged (pitted out) or destroyed by the LA-ICP-MS beam. As a result, a complete dataset is not available for all the investigated apatite grains. Due to their large size, multiple ablations were done on a single apatite grain. Ablations sites varied from the centre to the rim of the apatite grains. Once the data was obtained, it was reduced offline using Iolite v.3.7 and the UcomPbine DRS of [30].

\section{Results}

Apatite occurs in most of the variably mineralized quartz veins in the study area. In the studied samples, apatites are commonly fractured, complexly zoned, and form euhedral to anhedral crystals between 30 - $100 \mu \mathrm{m}$ (Figure 3-4). Larger (>200 $\mu \mathrm{m}$ ) apatite grains were observed in the Ptarmigan vein. In many cases, apatite displays a mottled texture due to the presence of sub-micron to nanometre-scale inclusions of pyrite, as well as monazite and tourmaline. Previous researchers have interpreted this as an effect of fluid percolation (e.g., [31]). Cathodoluminescence imaging revealed distinctive changes in the CL-colour from core to rim. Although the host rocks varied from black siltstones to greywacke, there was no correlation between host rock the measured REY abundance. Apatite commonly is found at the vein margins and accounts for up to 1-5\% of vein material.

\subsection{Cathodoluminescence and Micro-XRF Element Variation}

The apatite examined in this study exhibits near homogeneous cathodoluminescence (Figure 34), with brighter patches in some samples. The apatite taken from the Ptarmigan vein (sample P-14) consist of at least two generations: (1) a darker first-generation apatite that forms much of the grain, and (2) a brighter CL apatite that forms the rim and fills in fractures in early apatite. Variations in CL were confirmed utilizing micro-XRF ( $\mu$-XRF) trace-element maps. The micro-XRF maps of apatite from sample P-14 exhibit relative Mn-rich cores and Mn-poor rims. Spot analyses were preformed via LA-ICP-MS on the two generations. The early, darker CL apatite has higher $\mathrm{Sr}, \mathrm{Mn}, \mathrm{Zn}, \mathrm{Fe}, \mathrm{Pb}$, Th, and $U$, and low REE and $Y$ contents. The second-generation apatite is brighter in CL and is associated with low $\mathrm{Sr}, \mathrm{Mn}, \mathrm{Zn}, \mathrm{Fe}, \mathrm{Pb}$, and higher REE and $\mathrm{Y}$ contents.
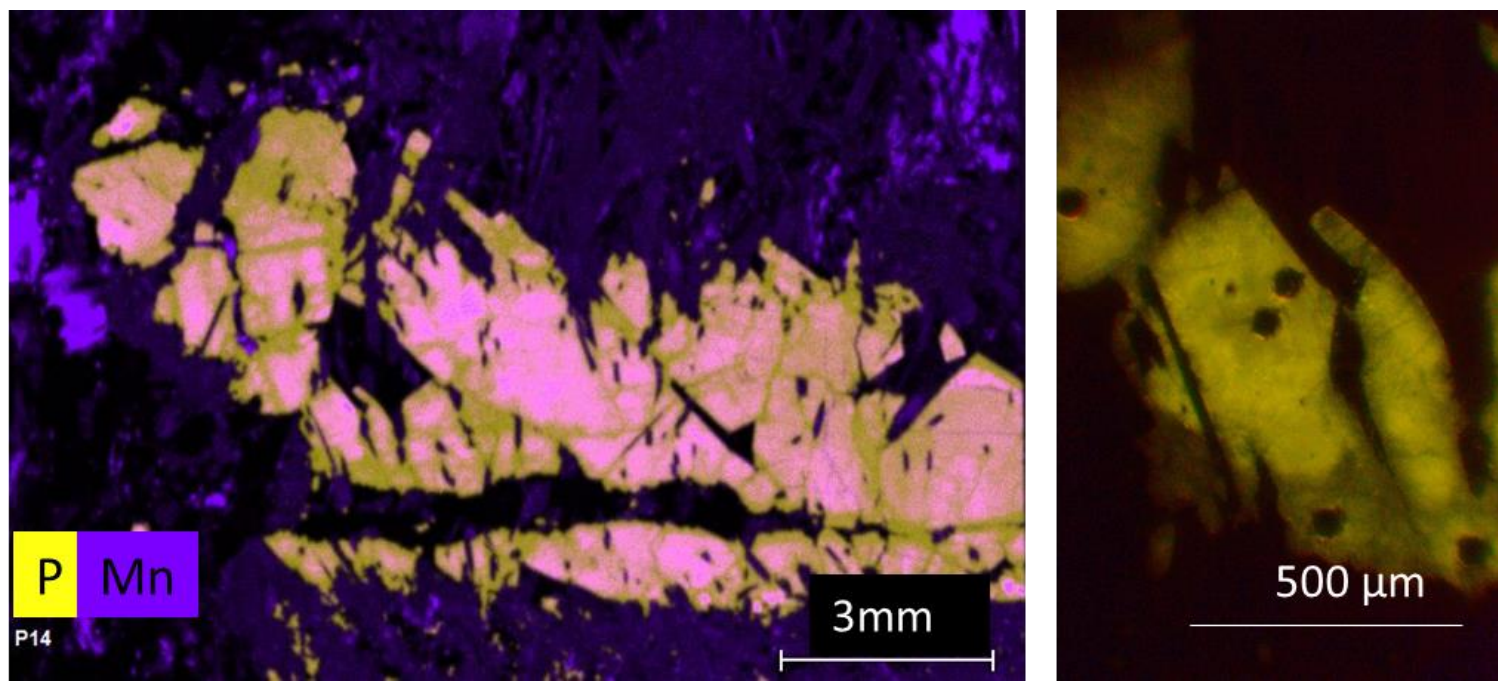


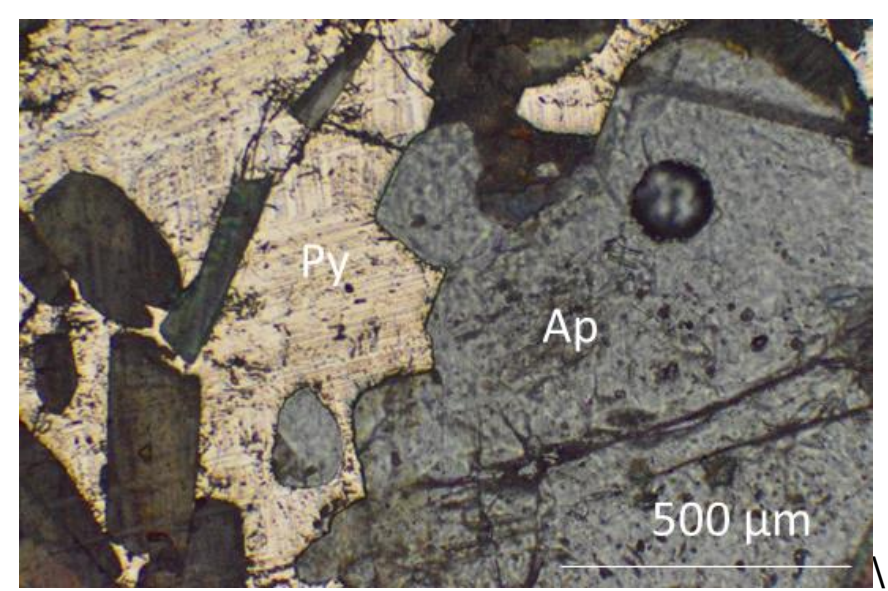

Figure 3: Top Left: P-Mn element map of sample P-14 taken from the Ptarmigan vein. The P-Mn element map reveals compositional zonation. Top Right: Cathodoluminescence emission spectra plots intensity vs. wavelength of sample P-14 (dark holes are from LA-ICP-MS spot) Bottom: Reflected light image of apatite grain inclusion in pyrite (sample P-14).

\subsection{LA-ICP-MS - trace-element concentrations}

\subsubsection{REE and yttrium}

Rare earth element (REE) patterns for quartz vein-hosted apatite are shown in Figure 4 and apatite from LCT pegmatites are shown in Figure 5. Characteristic chondrite-normalized (CN) patterns of REY, the vein-hosted apatite can be grouped into (5) distinct sub types, based on the values from [32]: type $-\mathbf{i}$ apatite exhibits negatively sloped patterns with no Eu anomalies; type - ii apatite exhibits relatively flat patterns with positive Eu anomalies; type - iii apatite have positive slopes with weakly negative Eu anomalies; type - iv apatite exhibit concave up REE patterns (i.e., relatively lower MREEs than LREEs and HREEs) with positive Eu anomalies; and (type - v) apatite exhibit weak concave down patterns (relatively higher MREEs than LREEs and HREEs) and weak negative Eu anomalies. The trace-element data for each sample are presented (see Appendix A). LCT-pegmatite-hosted apatite contains contrasting REE patterns. Sample MR-002 is relatively enriched in MREE producing a strong concave down pattern. Sample MR-003 is characterized by a broadly concave down pattern with a strong negative Eu anomaly. Sample MR-005 has a negatively sloped REE pattern resembling (type - i) apatite. The trace-element data for the pegmatite-hosted apatite are presented (see Appendix B). REY (REE $+Y$ ) substitute into apatite via coupled substitution processes. The REE $+\mathrm{Y}$ are correlated well with Na (Figure 6; a), which suggests that REE + Y were mainly incorporated via the following (Equation 1) coupled substitution reaction (e.g., [33-34]):

$$
(\mathrm{REE}+\mathrm{Y})^{3+}+\mathrm{Na}^{+}=2 \mathrm{Ca}^{2+},
$$

Brighter in CL in sample P-14 (associated with low $\mathrm{Sr}, \mathrm{Mn}, \mathrm{Zn}, \mathrm{Fe}, \mathrm{Pb}$, and higher REE and $\mathrm{Y}$ contents) was found to have relatively flat CN-REE patterns with greater concentrations of REEs $+Y$ and rims with negatively sloped $\mathrm{CN}$ patterns and less REEs.

Binary plots (Figure 6) allow for easy comparison of LREE-, MREE-, and HREE-enrichment patterns for both LCT- and vein-hosted apatite. $(\mathrm{Gd} / \mathrm{Yb})_{\mathrm{N}}$ versus $(\mathrm{La} / \mathrm{Yb})_{\mathrm{N}}$ biplot (Figure $6 \mathrm{~b}$ ) of all apatite shows a distinct positive correlation. The $(\mathrm{La} / \mathrm{Sm})_{\mathrm{N}}$ versus $\left(\mathrm{Eu} / \mathrm{Eu}^{*}\right)($ Equation 2$)$ biplot (Figure 6c) shows a clear negative correlation between REE composition and the magnitude of the Eu anomaly. In detail there are two groups of data that plot along this trendline. In the first group are the type - iii, type - iv, and type - v apatites and the second group contains the LCT pegmatites 

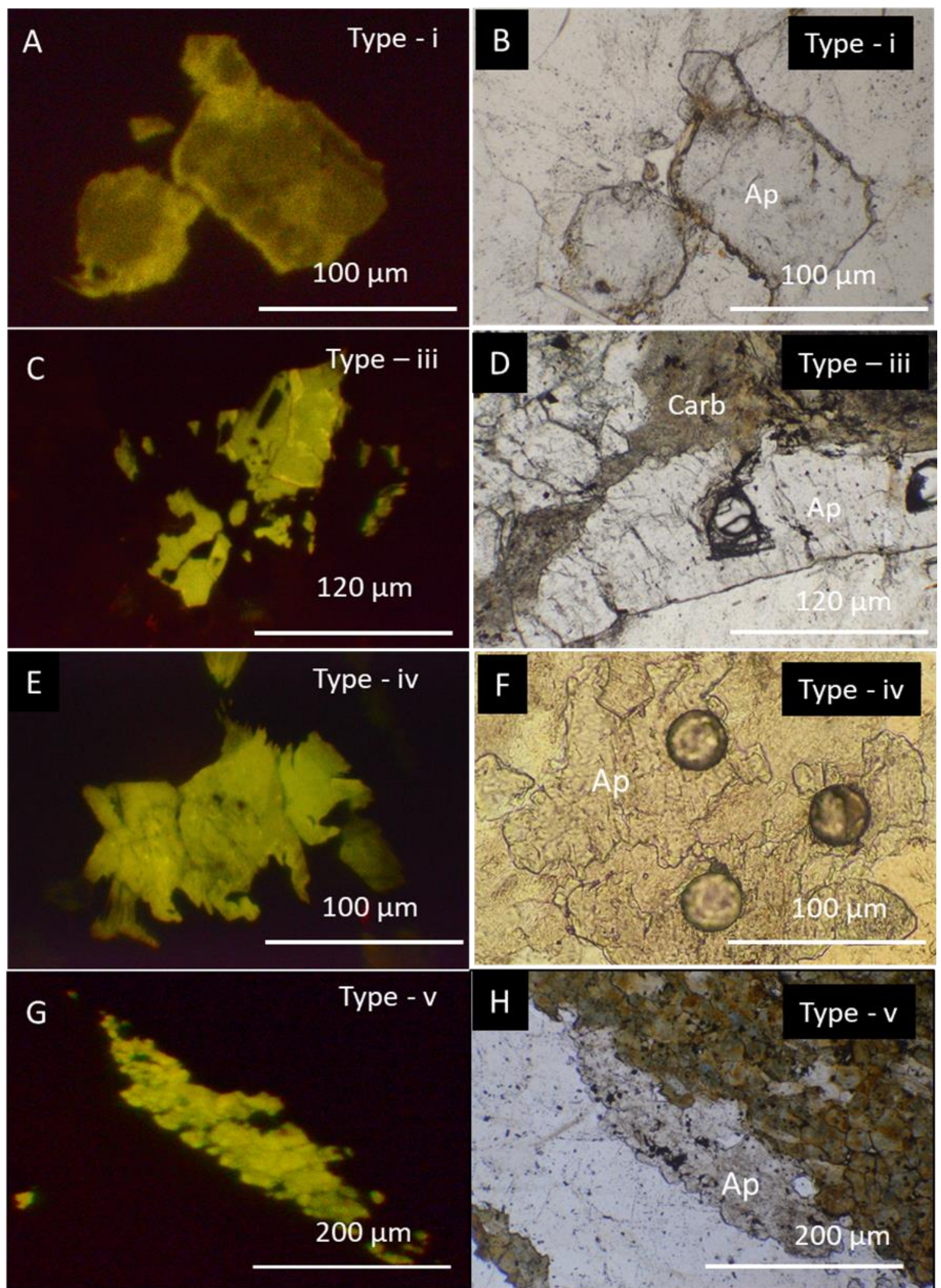

Figure 3: $(A, C, E, G)$ Cathodoluminescence images of apatite ( ${ }^{*}$ type - ii apatite see figure 4) next to $(\mathrm{B}, \mathrm{D}, \mathrm{F}, \mathrm{H})$ Plane polarized light image of apatite with assemblages in veins.

and type - I, and type - ii apatite. Biplots of $(\mathrm{La} / \mathrm{Yb})_{\mathrm{N}}$ versus $\left(\mathrm{Eu} / \mathrm{Eu}^{*}\right)$ also show that apatite cluster into two groups (Figure $6 \mathrm{~d}$ ). Apatite from type - iii, type - iv, and type - v plot with lower $(\mathrm{La} / \mathrm{Yb})_{\mathrm{N}}$ ratios with respect to type $-\mathrm{i}$, type $-\mathrm{ii}$, and LCT pegmatite-hosted apatite. Biplot of $(\mathrm{La} / \mathrm{Sm})_{\mathrm{N}}$ versus $(\mathrm{Sm} / \mathrm{Yb})_{\mathrm{N}}$ also cluster the REE apatite data into two separate groups (Figure $6 \mathrm{e}$ ). The first group type - iii, type - iv, and type $-\mathrm{v}$ apatite. The second grouping contains the LCT-pegmatites, type $-\mathrm{i}$, and type - ii apatite. 
A negative or positive correlation between $\mathrm{Ce}$ and Eu relates to the oxidation state [33]. In the studied apatite the $\delta \mathrm{Ce}$ anomalies (Equation 2, [35]) are mostly between 0.85 and 1.2 in the studied apatite. Additionally, these Ce anomalies are negatively correlated to $\delta \mathrm{Eu}$ anomalies (Equation 3, [35]) (Figure 6f)

$$
\begin{aligned}
& \frac{\mathrm{Ce}}{\mathrm{Ce}^{*}}=\frac{\mathrm{Ce}_{\mathrm{CN}}}{\sqrt{\mathrm{La}_{\mathrm{CN}} \times \mathrm{Pr}_{\mathrm{CN}}}} ; \\
& \frac{\mathrm{Eu}}{\mathrm{Eu}^{*}}=\frac{\mathrm{Eu}_{\mathrm{CN}}}{\sqrt{\mathrm{Sm}_{\mathrm{CN}} \times \mathrm{Gd}_{\mathrm{CN}}}} ;
\end{aligned}
$$
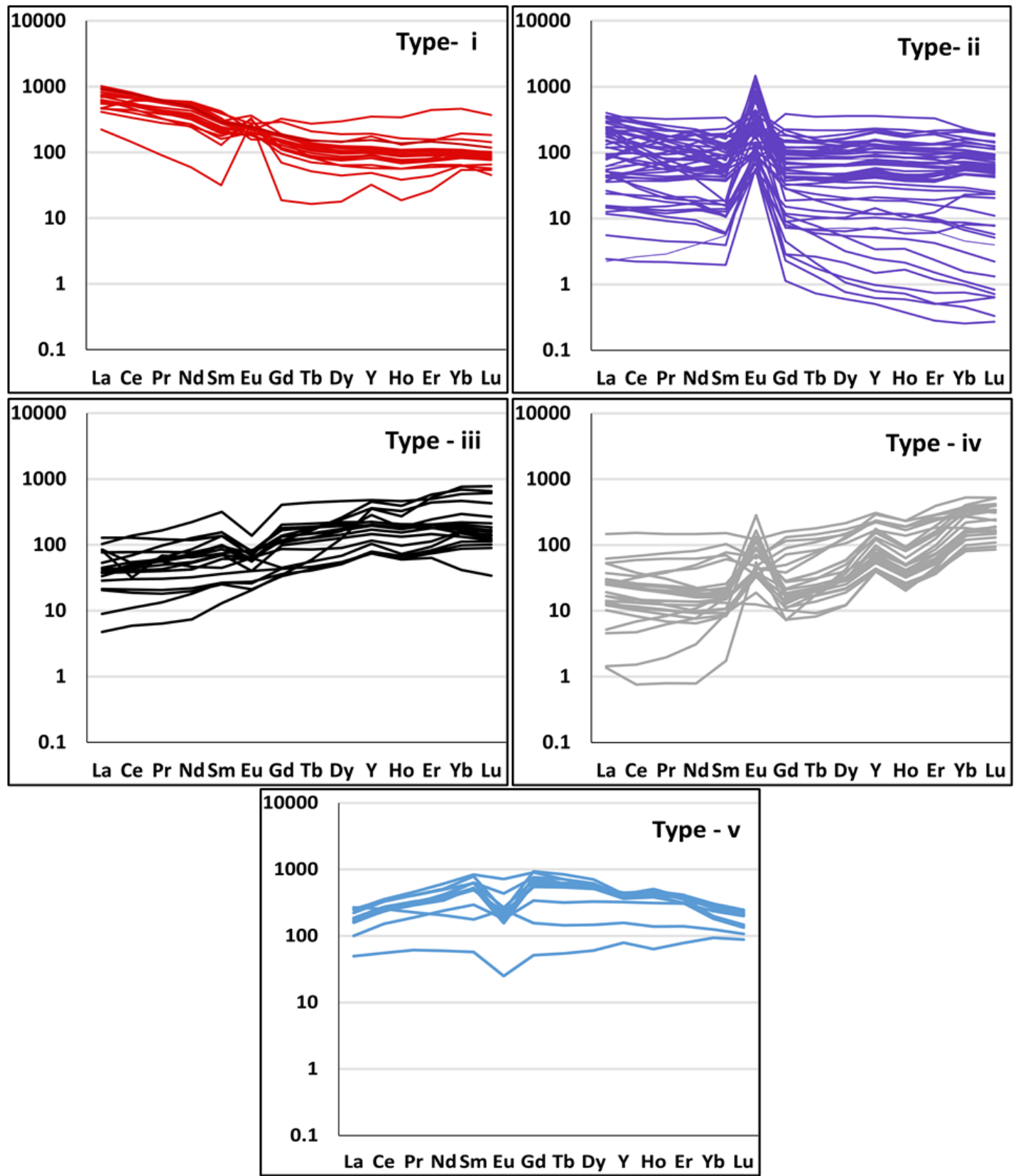

Figure 4: Chondrite-normalized REE and Y diagrams for LA-ICP-MS spot analyses of apatite in this study. The patterns are colour coded based on type (see Results and Discussion section). Chondritic values from [36]. 

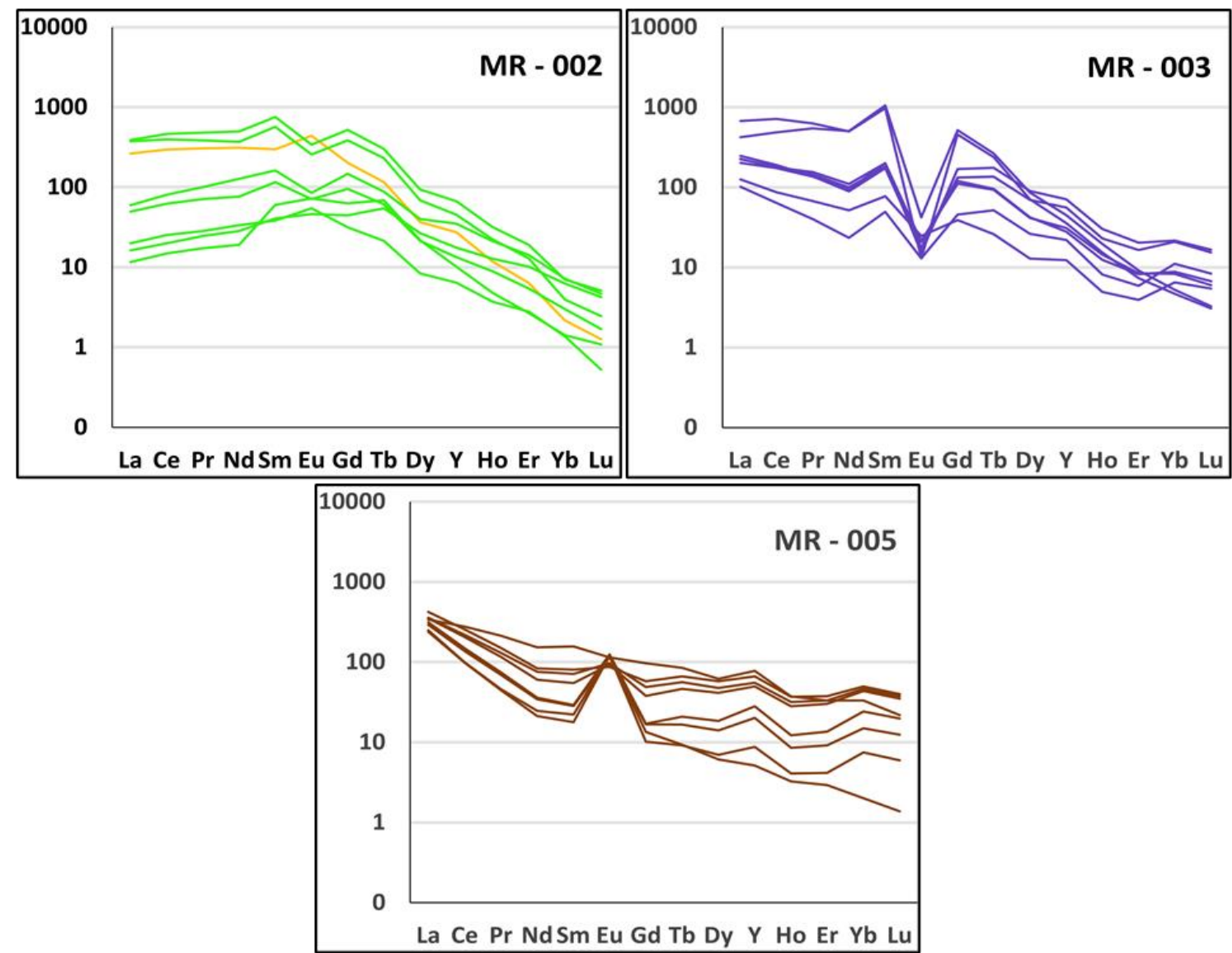

Figure 5: Chondrite-normalized REE and Y diagrams for LA ICPMS spot analyses of LCT-pegmatite hosted apatite. The patterns are colour coded based on type (see Results and Discussion section). Chondritic values from [36].

\subsubsection{LA-ICP-MS - Manganese, Lead, Yttrium, Iron, Strontium}

Manganese contents of the examined apatite are between 147 and 7551 ppm. Apatite collected from the Ptarmigan vein have the greatest Mn values (1000 - $7551 \mathrm{ppm})$ with the exception type-i apatite (collected from a zone of intense quartz hydrofracturing proximal to the mine shaft and the mineralized vein). The $\mathrm{Mn}$ concentrations are positively correlated with ${ }^{204} \mathrm{~Pb}$ concentration (Figure 7a) and $\mathrm{Sr}$ concentrations (Figure $7 \mathrm{~b}$ ). The concentration of ${ }^{204} \mathrm{~Pb}$ is independent of the $\mathrm{U}$ and $\mathrm{Th}$ concentration, therefore ${ }^{204} \mathrm{~Pb}$ concentrations are likely to be a better discriminator of fluid source. Additionally, the biplots separate the non-LCT pegmatite apatite and vein-hosted apatite into two distinct clusters. ${ }^{204} \mathrm{~Pb}$ concentrations are greatest in type $-\mathrm{i}$ apatite followed by apatite from type $-\mathrm{ii}$ mineralized quartz veins. Non-mineralized or barren quartz veins are depleted in both $\mathrm{Pb}$ and $\mathrm{Sr}$ with respect to type - i and type - ii apatite. Sr concentrations in the LCT pegmatites are lowest in sample MR-003 and highest in sample MR-002. Yttrium concentrations are negatively correlated to the $\mathrm{Mn}$ concentrations, except for high $\mathrm{Mn}$ apatite (sample P-14) (Figure 7 c). Highest $\mathrm{Y}$ concentrations are associated with the non-mineralized vein-hosted apatite, whereas the LCT pegmatites contain considerably lower concentrations. Iron concentrations plotted against $\mathrm{Mn}$ also cluster into two groups with two distinct trendlines (Figure $7 \mathrm{~d}$ ). The first group includes type - iii, type - iv, and type $-\mathrm{v}$ apatite. This group has a strong positive correlation between Fe and $\mathrm{Mn}$ concentrations. The second group includes the LCT-pegmatites, type - i, and type - ii apatite; however, the type $-\mathrm{i}$ apatite plot slightly above the main cluster (i.e., enriched in $\mathrm{Fe}$ ). The biplot of $\mathrm{Mn}$ versus $\mathrm{Eu} / \mathrm{Eu}^{*}$ (Figure $7 \mathrm{e}$ ) shows that apatite from the LCT-pegmatites, type - I, and type - ii have greater concentrations of Mn than type - iii, type - iv, and type - v apatite. Furthermore, Mn concentrations show no correlation with respect to the magnitude of the Eu anomaly. Strontium concentrations in apatite range from 83 to $7300 \mathrm{ppm}$, with a mean of $1244 \mathrm{ppm}$ and a median of 653 
ppm. Apatite from mineralized veins contain the greatest concentrations of Sr (1000 - 3569 ppm), whereas the unmineralized veins contain $100-500 \mathrm{ppm}$ Sr. Biplots of $\mathrm{Sr}$ versus $\mathrm{Eu} / \mathrm{Eu}^{*}$ show that $\mathrm{Sr}$ concentrations are positively correlated to the magnitude of the Eu anomaly (Figure $7 \mathrm{f}$ ).

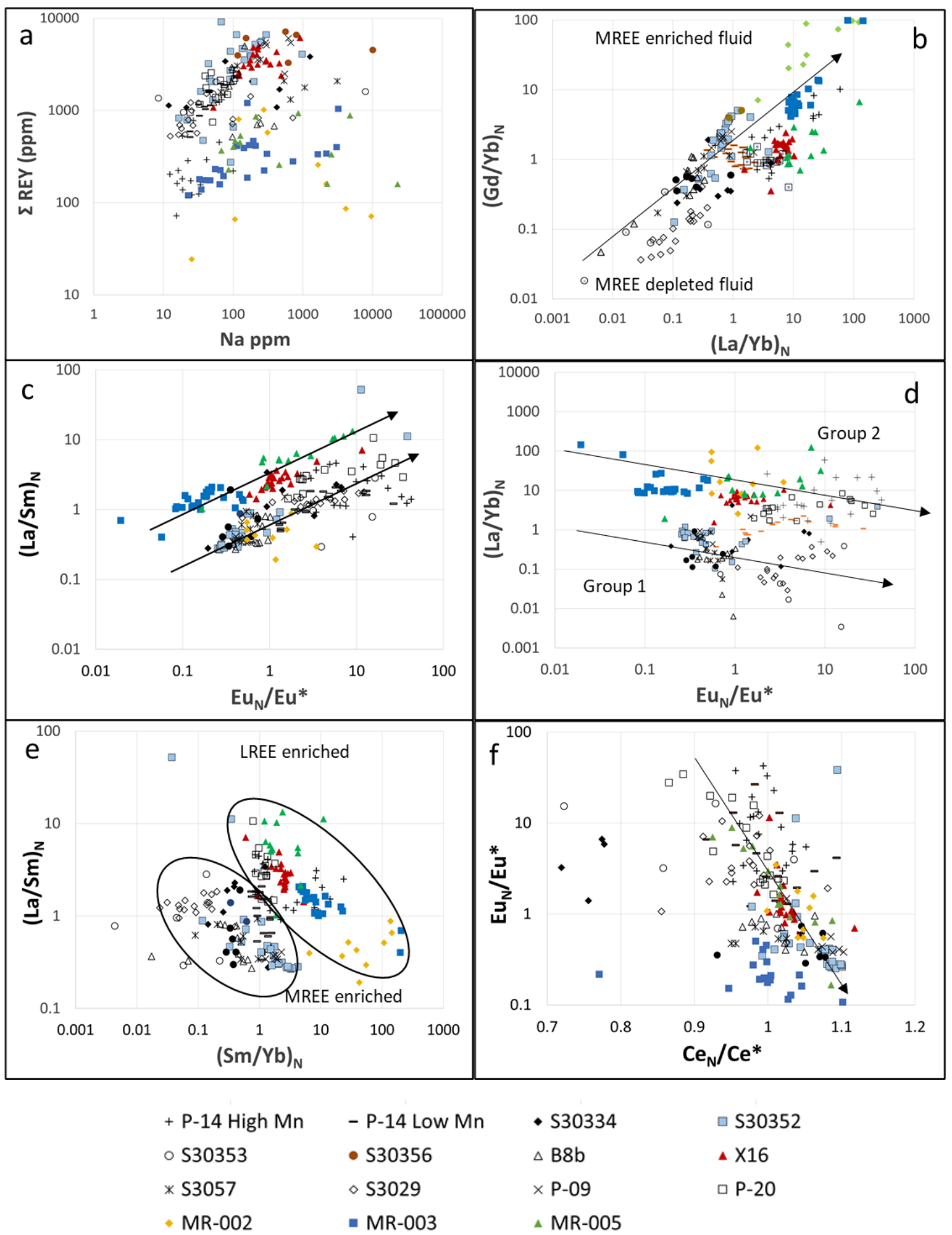

Figure 6. a) $\Sigma R E Y$ vs $\mathrm{Na} p p m$. b) $(\mathrm{Gb} / \mathrm{Yb})_{\mathrm{N}}$ vs $(\mathrm{La} / \mathrm{Yb})_{\mathrm{N}}$ bivariate plots illustrate the compositional differences that reflect the evolution of hydrothermal fluids from one enriched in MREE and depleted in HREE to ones depleted in MREE and enriched in HREE. c) ( $\mathrm{La} / \mathrm{Sm})_{\mathrm{N}} \mathrm{vs}$. $\left(\mathrm{Eu} / \mathrm{Eu}^{*}\right) \mathrm{cn}$ bivariate plot illustrating the co-evolution of two hydrothermal fluids. Increases in MREE is also observed to correlate with an increase in the Eu anomaly. d) $(\mathrm{La} / \mathrm{Yb})_{\mathrm{N}} \mathrm{vs}$. Eu/Eu*n shows that the LREE/HREE elements plot into four separate clusters. Apatite from samples P-14 (high and low Mn) and P-20 are 
partitioned with the cluster that includes two samples taken from the LCT-pegmatite dikes. d) Biplot of $(\mathrm{La} / \mathrm{Yb})_{\mathrm{N}}$ versus $\mathrm{Eu} / \mathrm{Eu}^{*}$ illustrating the trends of the two clusters of apatite. e) $(\mathrm{La} / \mathrm{Sm})_{\mathrm{N}}$ versus $(\mathrm{Sm} / \mathrm{Yb})_{\mathrm{N}}$ biplot show how hydrothermal fluids may have evolved along two independent trajectories. f) $\mathrm{Ce} / \mathrm{Ce}^{*}$ versus $\mathrm{Eu} / \mathrm{Eu}^{*}$ indicated that a negative correlation exists.

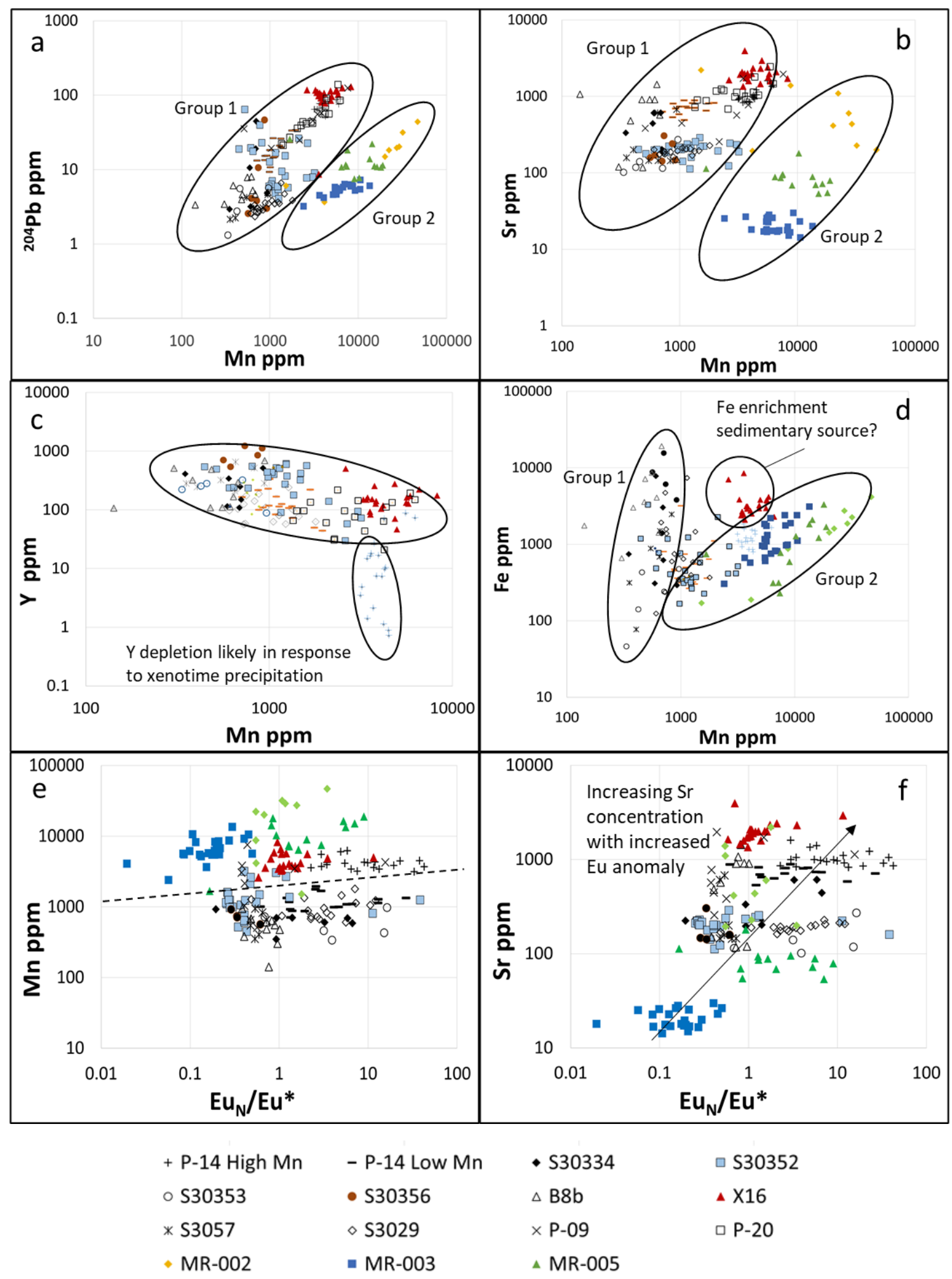

Figure 7. a) Bivariate plot of $\mathrm{Mn}$ versus $\mathrm{Pb}$ illustrating the positive correlation between $\mathrm{Mn}$ and $\mathrm{Pb}$ concentrations. Group 1 contains apatite from mineralized and non-mineralized quartz veins, whereas Group 2 contains apatite from the LCT pegmatites. b) Biplot of Mn versus Sr illustrating the positive correlation between $\mathrm{Mn}$ and $\mathrm{Sr}$ concentrations. Group 1 contains apatite from non- 
mineralized quartz veins, whereas Group 2 contains apatite from the LCT pegmatites and mineralized quartz veins. c) Biplot of $Y$ versus Mn illustrating the negative correlation between $Y$ and Mn. Additionally, this plot shows that Mn-rich apatite taken from the Ptarmigan vein plot as a separate cluster likely indicating that $\mathrm{Y}$ was sequestered in xenotime. d) Biplot of Mn versus $\mathrm{Fe}$ illustrating the positive correlation between $\mathrm{Mn}$ and Fe concentrations. Group 1 contains apatite from non-mineralized quartz veins, whereas Group 2 contains apatite from the LCT pegmatites and mineralized quartz veins. e) Biplot of $\mathrm{Mn}$ versus $\mathrm{Eu} / \mathrm{Eu}^{*}$ illustrating that apatite from the LCTpegmatites, type - i, and type - ii have greater concentrations of Mn than type - iii, type - iv, and type - v apatite. f) Biplots of $\mathrm{Sr}$ versus $\mathrm{Eu} / \mathrm{Eu}^{*}$ show that $\mathrm{Sr}$ concentrations are positively correlated to the magnitude of the Eu anomaly.

\subsubsection{LA-ICP-MS - Uranium, Thorium, and Lead}

$\mathrm{U}, \mathrm{Th}$, and $\mathrm{Pb}$ can replace $\mathrm{Ca}$ in apatite. Although $\mathrm{Pb}^{2+}$ can directly substitute for $\mathrm{Ca}^{2+}$, the incorporation of $\mathrm{Th}^{4+}$ and $\mathrm{U}^{4+}$ cations require a vacancy to maintain charge balance [33]. In the quartz vein-hosted apatite, the $U$ and Th contents are low $0.5-10 \mathrm{ppm}$ in comparison to the LCT pegmatites that have concentrations that range from 9 to $180 \mathrm{ppm}$. It is noted that $U$ and Th contents of apatite taken from the Ptarmigan vein are on average greater than the non-mineralized veins, except for sample $X-16$. The $U$ and Th concentrations do not show any correlation with $\Sigma R E Y$ concentrations (Figure 8). Furthermore, $\mathrm{U}$ and Th are not correlated with Y, HREE, or Eu anomaly.

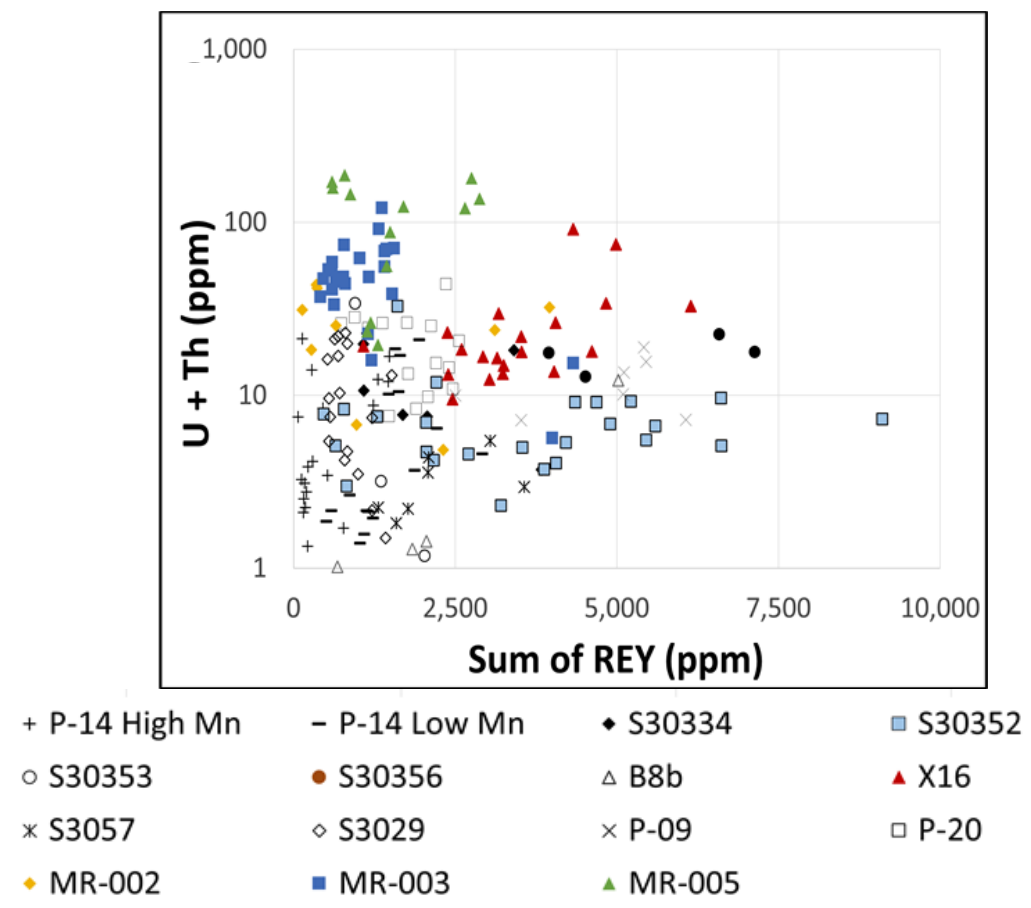

Figure 8. Bivariate plot of a) $U+T h(p p m)$ versus $\Sigma$ REY

\subsection{U-Pb in situ Hydrothermal Apatite Geochronology}

Uncorrected common- $\mathrm{Pb}$ data from the hydrothermal apatite was plotted on a Tera-Wasserburg concordia plot (Figure 9), where ${ }^{238} \mathrm{U} / 206 \mathrm{~Pb}$ is plotted along the $\mathrm{x}$-axis and ${ }^{207} \mathrm{~Pb} / 206 \mathrm{~Pb}$ is plotted along the y-axis. Tera-Wasserburg concordia plots are used to calculate concordia-intercept ages. The analysis assumes that samples (uncorrected for common $\mathrm{Pb}$ ) are cogenetic and diverge from concordia because of variable contamination with common- $\mathrm{Pb}$ with a restricted ${ }^{207 \mathrm{~Pb} / 206 \mathrm{~Pb}}$ composition. Therefore, a linear regression through the series of discordant points will intercept the concordia at the age of initial crystallization. Theoretically this is true; however, the data is likely to have non-target phases (e.g., inclusions or neighboring grains), or record differential $\mathrm{Pb}$ loss that disperses data towards lower $238 \mathrm{U} / 206 \mathrm{~Pb}$ values. Therefore, it was necessary to refine the linear 
regression to obtain the lowest Mean Square of the Weighted Deviates (MSWD), while using the greatest number of data points possible. After omitting data via weighed residuals and data with large errors, a liner regression yielded an age of $2590 \pm 13 \mathrm{Ma}(\mathrm{MSWD}=0.94)(\mathrm{n}=88 / 284)$ from 10 different samples (P20, P-15, P-14, P-09, S3063, S3052, S3052b, X-16 and B8a/b).

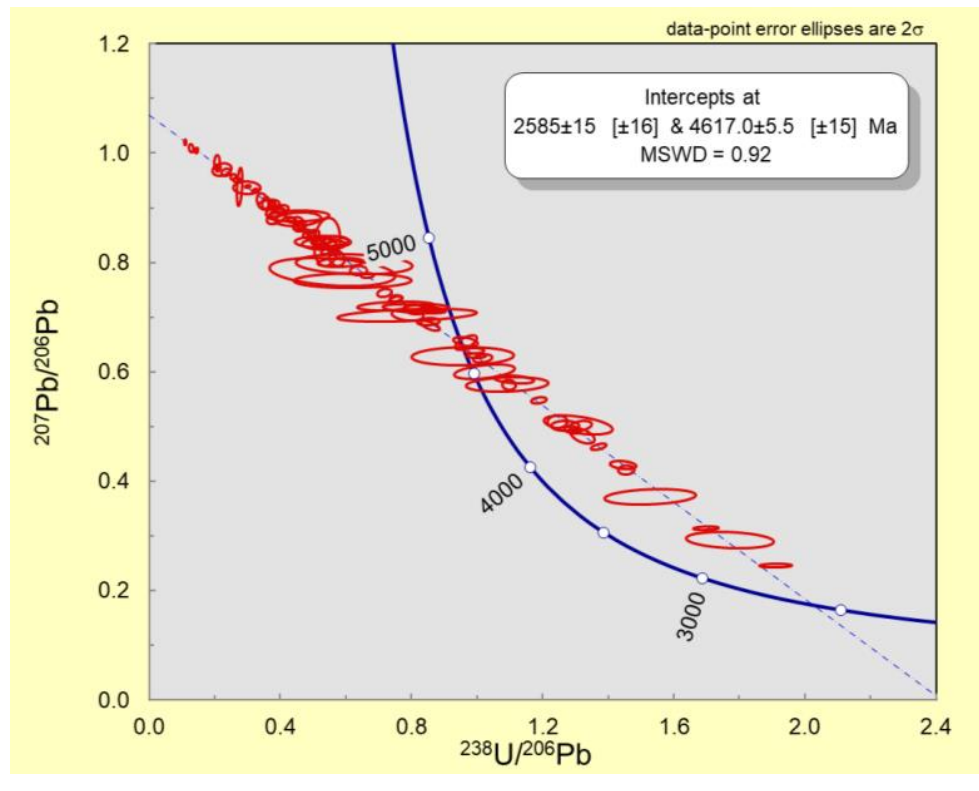

Figure 9. $\mathrm{U}-\mathrm{Pb}$ apatite isochron for hydrothermal quartz veins. Anchored regression lower intercept at $2585 \pm 15 \mathrm{Ma}$; upper intercept anchored terrestrial common-Pb value at $2600 \mathrm{Ma}$ (1.066) [29]. Error ellipses are $2 \sigma$.

\subsection{U-Pb in situ LCT-Pegmatite Hosted Apatite Geochronology}

The range of LCT-pegmatite apatite ages were plotted on a conventional concordia (Wetherill) diagram. The weighted mean ${ }^{207} \mathrm{~Pb} / 206 \mathrm{~Pb}$ ages were determined based on ${ }^{204} \mathrm{~Pb}$-corrected isotope ratios. Common- $\mathrm{Pb}$ correction utilized the measured ${ }^{204} \mathrm{~Pb}$ assuming an initial $\mathrm{Pb}$ composition from [36] $\mathrm{Pb}$ evolution model. In this model, no assumptions of $\mathrm{U} / \mathrm{Pb}^{*}$ concordance are made, allowing for identification of concordance of the ${ }^{204} \mathrm{~Pb}$-corrected data [30]. Apatite typically incorporates substantial amounts of common- $\mathrm{Pb}$ compared to $\mathrm{U}$ when it crystallizes, leading to a low ${ }^{238} \mathrm{U} /{ }^{204} \mathrm{~Pb}$ ratio. Lead loss is generally regarded as the most important cause for age discordance [37]. Additionally, discordance (normal or reverse) may be attributed to mobility of $\mathrm{Pb}$ and $\mathrm{U}$ during dynamic recrystallization or dissolution-reprecipitation reactions [27]. Plotting of the LCT-Pegmatite data revealed that several analyses fall above and below concordia, reflecting minor matrix-mismatch and recent $\mathrm{Pb}$ loss. By examining the near-concordant ${ }^{204} \mathrm{~Pb}$-corrected data (Figure 10; a) of the LCT pegmatite hosted apatite two clusters of ages emerge. An older population with an intercept age $(\mathrm{n}=$ 4) of $2581 \pm 15 \mathrm{Ma}$ (Figure 10; b), and a younger population with an intercept age $(n=3)$ of $2519 \pm 12$ Ma (Figure 10; c). Furthermore, plotting a regression through all near - concordant data for the pegmatite hosted apatite hints that metamorphic resetting occurred around $2200 \mathrm{Ma}$ (Figure 10; d). It is likely that detailed imaging using a scanning electron microscopy (SEM) of these apatite grains may reveal older domains. 

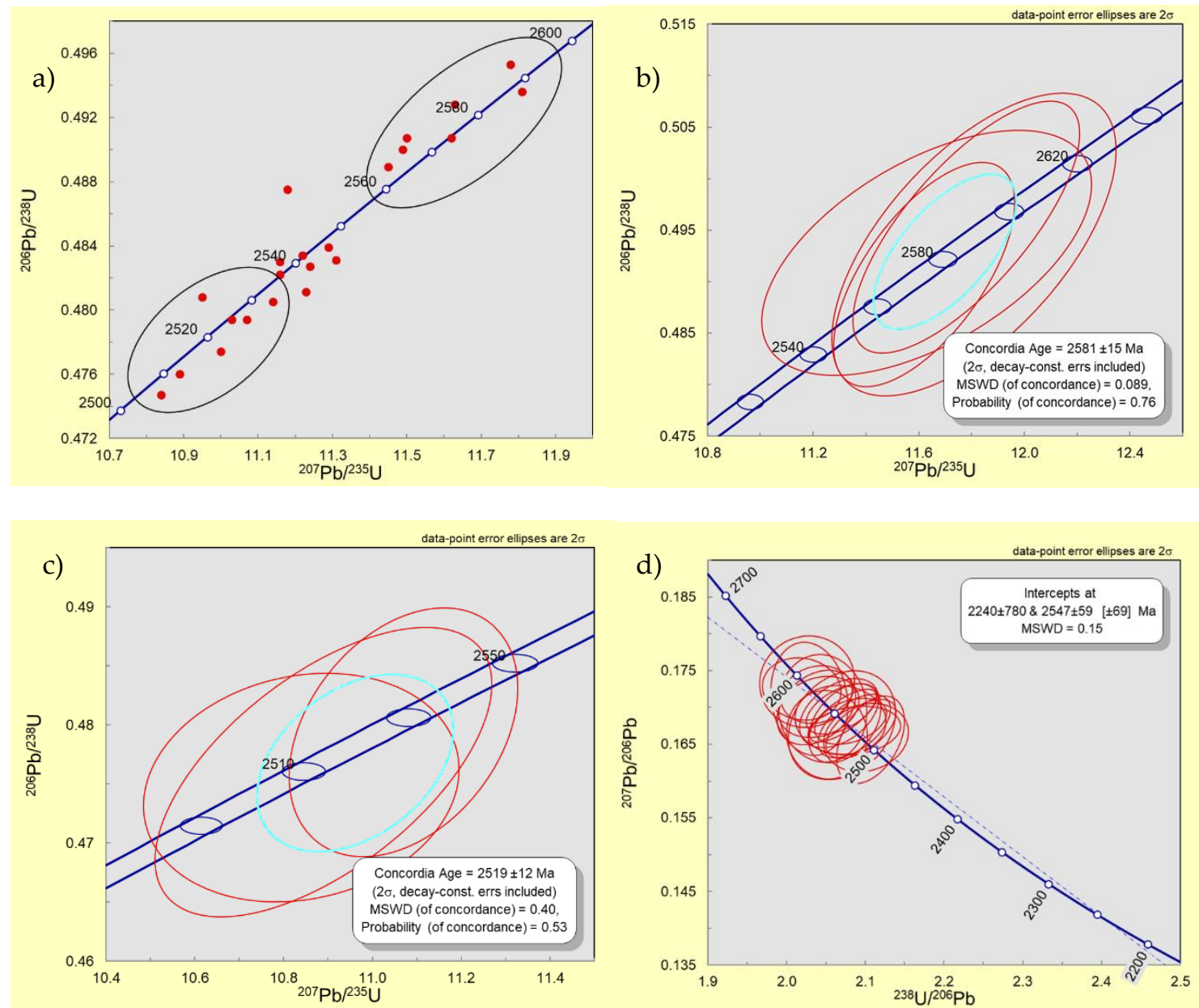

Figure 10. a) Plots of near-concordant ${ }^{204} \mathrm{~Pb}$-corrected data of the LCT pegmatite-hosted apatite illustrating two clusters of ages that emerge; b) LCT pegmatite-hosted apatite focused on the older cluster with a concordant age $(n=4)$ of $2581 \pm 15 \mathrm{Ma}$; c) LCT pegmatite-hosted apatite focused on the younger cluster with a concordant age $(n=3)$ of $2519 \pm 12$ Ma; d) Error ellipses are $2 \sigma$. Linear regression through all near - concordant data for the pegmatite-hosted apatite hints that metamorpic resetting occurs around $\sim 2200 \mathrm{Ma}$.

\section{Discussion}

Hydrothermal apatite forms large (up to $5 \mathrm{~mm}$ ) subhedral to euhedral crystals and occurs within most quartz veins in the study area. Petrological observations suggest that apatite is precipitated early, as sulphide-bearing phases are observed to infill fractures and occasionally partially surround apatite grains. Additionally, in the gold-bearing Ptarmigan vein, tourmaline is found as inclusions in apatite.

The spectra observed via cathodoluminescence and micro-XRF mapping revealed compositional variations with respect to trace-elements in most of the examined apatite grains. This spectral variation is explained by compositional zoning in apatite. In order to determine whether the compositional zoning reflects primary elemental distributions and abundances, the REE abundances and zonation were contrasted with the $(\mathrm{La} / \mathrm{Sm})_{\mathrm{N}}$ established conditions [38]. Additionally they also noted that since LREEs-MREEs are readily substituted into the $\mathrm{Ca}(2)$ site, homogenization of $(\mathrm{La} / \mathrm{Sm})$ ratios between compositional zones may elucidate whether intragrain diffusion of elements has occurred [38]. If post-crystallization, intra-grain diffusion of LREEs-MREEs in apatite has occurred, there will be an absence of zone-to-zone variation in La/Sm within a single grain. Most of the apatite grains were too small to perform detailed trace element spot analysis. However, the apatite in sample P-14 was large enough to use LA-ICP-MS spot analysis on the observed spectral zonation observed by cathodoluminescence and micro-XRF trace element maps. As noted above, reflected light 
petrography and micro-XRF trace element maps of sample P-14 indicate the presence of tourmaline inclusions in the apatite grain. The inclusions of tourmaline in the apatite were small enough to avoid, with careful placement of the laser spot. Sample P-14 had two clearly identifiable zones (core and rim) in micro-XRF mapping. The core of the apatite grain appeared enriched in manganese and depleted in REY with respect to the rim (Figure 2). CL-imaging of the apatite grains indicated that yellow was the main colour of the CL emission among the studied apatite grains. The core of P-14 had $\mathrm{La} / \mathrm{Sm}$ values ranging from 0.91 to 4.61 , whereas the surrounding rims are found with lower $\mathrm{La} / \mathrm{Sm}$ varying between 0.34 and 2.09. Therefore, based on the zone-to-zone variation of $\mathrm{La} / \mathrm{Sm}$ in sample P-14, intra-grain diffusion did not occur, and the observed zoning pattern of apatite records the primary distribution of elements. This zonation pattern developed (as [39] suggest) from changes in the hydrothermal system, such as varying fluid composition, pressure, temperature, as well as changes in mineral growth rate and not as separate and distinct hydrothermal events.

It was found that the fluids responsible for deposition of intergrown quartz and tourmaline in gold-bearing vein samples from the Ptarmigan vein had a temperature of $560^{\circ}$ to $600^{\circ} \pm 50^{\circ} \mathrm{C}$ [40]. Additionally, the arsenic concentrations in the Ptarmigan also indicated that the mineralizing fluid was $550^{\circ} \pm 50^{\circ} \mathrm{C}$ supporting the role of a high-temperature fluid in formation of these gold deposits. The character of wall-rock alteration adjacent to the Ptarmigan veins also supports that the vein formed at a high temperature. Furthermore, they [40] found that the "static" growth of cordierite porphyroblasts in wall rocks that host the Ptarmigan deposit indicates that the country rocks experienced temperatures of $\geq 500^{\circ} \mathrm{C}$ during amphibolite-grade metamorphism.

\subsection{Trace element substitution}

Elements can substitute into apatite either by direct (i.e., the substituting element has a charge and effective ionic radius compatible with that of the element it is replacing) or by heterovalent substitution (i.e., coupled substitution or the presence of a vacancy). For any given element to substitute into apatite, it must adhere to Goldschmidt's Rules. Thus, elements with an ionic radius closest to the substituted ion will preferentially be incorporated into apatite. For example, substitution of REY in apatite follows two rules based on the availability of the two Ca positions in apatite: The LREE preferring the Ca2 site and the HREE the Ca1. The selective incorporation of REEs into apatite is driven by crystallographic features and by fluid composition and temperature [15].

The trace element composition of apatite is dependent on the hydrothermal fluid composition, host rock composition, temperature, pressure, $\mathrm{pH}$, and $\mathrm{fO}_{2}$, as well as the partition coefficients between fluid, apatite, and co-precipitating minerals. It was noted that auriferous hydrothermal fluids in orogenic gold deposits are typified as forming from mixed aqueous-carbonic fluid with a low salinity with a minor difference in composition [9]. Additionally, these fluids have been shown to contain $\mathrm{Na}$, minor $\mathrm{K}$ and $\mathrm{B}$, and low levels of trace elements [41]. However, in the present study area, the concentrations of REEs show measured variation in apatite taken from different quartz veins. This contrasts with low variance in hydrothermal fluid compositions in orogenic gold deposits.

The hydrothermal apatite in the study area exhibits five different REE patterns. Since the behavior of the REE in hydrothermal fluids is most affected by parameters, such as $\mathrm{pH}$, temperature, salinity, redox conditions, and fluid composition, it follows that changes in these parameters are the most likely explanations for the variation in apatite REE patterns. In any hydrothermal system, changes in REE parameters are a result of the preferential incorporation of REEs into co-crystallizing phases; or due to changes in fluid composition in response to an evolution from metamorphically derived fluid to a magmatically derived fluid. The chondrite-normalized $\mathrm{La} / \mathrm{Yb}, \mathrm{La} / \mathrm{Sm}$, and $\mathrm{Gd} / \mathrm{Yb}$ ratios (Figure 6) show distinct trends that track fluid that reflect the evolution of the fluid or the partitioning of REE among apatite and other co-crystallizing phases. It is apparent that two distinct fluid compositions (a magmatic and metamorphic fluid) are responsible for precipitation of the apatite observed in this study. This concept was previously suggested [40], as they found that the Ptarmigan deposit was likely formed by at least two mineralizing fluids. The first fluid, a $\sim 380^{\circ} \mathrm{C}$ $\mathrm{H}_{2} \mathrm{O}-\mathrm{CO}_{2}$ fluid with dissolved solids, gas contents, and a temperature akin to fluids involved in the formation of nearby pegmatite dykes, was responsible for low grade $\mathrm{Au}$ (500 ppb). The second fluid, 
a $550^{\circ} \mathrm{C}, \mathrm{H}_{2} \mathrm{O}-\mathrm{CH}_{4}$ fluid of metamorphic origin, is thought to have deposited the high-grade gold in the core of the Ptarmigan vein.

Fluids derived from the adjacent S-type Prosperous plutons metasomatized the country rock during contact metamorphism, and that fluorine and phosphorus in the fluid complexed with $\mathrm{U}, \mathrm{Th}$, $\mathrm{Y}$, and REE. Consequently, these intrusions likely were an important source of $U$, REE, $Y$, as well as $\mathrm{P}$ and $\mathrm{F}$ for the studied mineralization.

Examining the CN-REE patterns in detail, type - i apatite have LREE enriched profiles with only a minor positive Eu anomaly. This LREE enrichment likely is a result of dehydration reactions during intrusion of the Prosperous Granite. This event would have released LREE-enriched fluid [15], since LREEs are generally more mobile than HREEs, the REE pattern of type $-i$ apatite is consistent with a metamorphically derived fluid. Additionally, magmatically driven hydrothermal fluids would inherit increased LREE along with $U$ and Th. Over time, concentrations of trace elements would be reduced as an increased abundance of other phases competing for the same elements would deplete their contents in hydrothermal fluids. It follows that trace element concentrations in type - ii apatite were inherited from these LREE depleted hydrothermal fluids. The metamorphically derived hydrothermal fluids account for the CN-REE patterns observed in type - iii, type - iv, and type - v apatite. In type - iii and type - iv apatite, an increase in HREE in the CN-patterns are best explained by the early or co-crystallizing LREE sinks (e.g., epidote, titanite, and calcite) that are observed to occur in thin section with type - iv apatite. In several studies examining scheelite from orogenic gold deposits (which partitions REEs like that of apatite, i.e., [40], REE patterns have been documented to evolve from a bell-shaped pattern with negative Eu anomalies (e.g., type - v apatite) to flat REE patterns with positive Eu anomalies (e.g., type- ii apatite) [43-44]. Interestingly, a REE-enriched bellshaped pattern (e.g., type - v apatite) was observed in samples from the Ptarmigan vein and a smaller gold-bearing vein on the Ptarmigan Mine property. Apatite from the Ptarmigan vein contains both type - ii and type - v REE patterns and reflect the change in the hydrothermal fluid from one that was metamorphically derived type $-v$ apatite to one that is magmatically derived (type $-i$ apatite).

Strontium is more mobile than the REE [45]; therefore, Sr concentrations in apatite formed at higher levels in the system will have inherited Sr concentrations. Comparatively, apatite from LCT pegmatites have much lower $\mathrm{Sr}$ than the vein-hosted apatites. This maybe a consequence of $\mathrm{Sr}$ scavenging in a closed hydrothermal system. In this scenario hydrothermal quartz veins are distal end members of the LCT-pegmatites found locally. It was observed that the intrusion-related gold at the Clarence Stream gold deposit in southwestern New Brunswick [46], which found that aplitic and granophyric granitic laterally change into auriferous sulfide-bearing quartz veins, appears to support this possibility. This suggests that $\mathrm{Sr}$ content in apatite was likely inherited from $\mathrm{Sr}$ concentrations in the host rocks as the hydrothermal fluids ascended thru the crust. Additionally, shales commonly have high $\mathrm{Pb}, \mathrm{U}$, and Th compared to other rock types [47], which may also explain why $\mathrm{Pb}, \mathrm{U}$, and Th signature in the type $-i$ apatite is elevated. This reasoning suggests that the host rock compositions have an influence on the trace element composition because of the reaction and exchange between hydrothermal fluids and host rocks e.g., [9,48].

Apatite is not observed to overprint any mineral phases and likely precipitated early. It is interpreted that apatite documented in this study are primary hydrothermal apatite that record the initial fluid compositions.

The source of U, REE, Y, as well as P and F for the studied mineralization was likely derived from melting of the Burwash sedimentary package during crustal anatexis. The evolution of a fluid phase from a melt is controlled by the solubility of $\mathrm{H}_{2} \mathrm{O}$ in the melt, which is in turn dependent on temperature, pressure, and composition. The Prosperous plutons are interpreted as $2 \mathrm{~km}$ thick silllike intrusive sills emplaced at depths between 9 and $13 \mathrm{~km}\left(3.0-3.5 \mathrm{kbar}(300-350 \mathrm{MPa})\right.$ and $550^{\circ} \mathrm{C}$; [49]). As sill-like intrusions cool, a boundary zone forms at the margins of the body. The last region to cool is the core. This cooling and crystallization of the magma causes saturation, and evolution of a $\mathrm{H}_{2} \mathrm{O}$-rich volatiles. As crystallization continues, one of two events must occur, either the magma expands, or the internal pressure increases. Once internal pressures overcome the lithostatic load, fracturing occurs in the vertical plane [50]. This allows fluids to be channeled upwards. These fluids contain metals, $\mathrm{S}, \mathrm{Cl}$, and $\mathrm{CO}_{2}$ that have been separated from the cooling magma. Additionally, REEs 
are shown to form stable complexes with $\mathrm{Cl}$ [51]. The high concentrations of $\mathrm{Cl}$ exsolved from a pluton may transport large amounts $\mathrm{Ca}$ as $\mathrm{Ca}-\mathrm{Cl}$ and $\mathrm{REE}-\mathrm{Cl}$ complexes, which may react with $\mathrm{H}_{3} \mathrm{PO}_{4}$ complexes leading to the crystallization of apatite. Furthermore, sericitization of host rock likely elevated $\mathrm{Ca}^{2+}$ activity in the hydrothermal fluid. As a result, the elevated $\mathrm{Ca}^{2+}$ content this would limit the precipitation of monazite, while promoting the saturation and growth of apatite. At temperatures greater than $350^{\circ} \mathrm{C}$ (such as in magmatic-hydrothermal systems) and low $\mathrm{pH} \mathrm{Au} \mathrm{Au}^{+}$forms stable bonds with harder anions such as $\mathrm{Cl}^{-}$[21]. Therefore, with decreasing temperature from magmatic to $<350^{\circ} \mathrm{C}$ facilitated gold saturation.

Lastly, boron- and F-bearing volatiles likely escaped from this proximal granite intrusion into the adjacent metamorphic rocks. The margins of the quartz veins and the pegmatites observed at the Ptarmigan and Tom deposits typically have tourmaline-rich rims. [52] suggests that boron rich vapors were channelized along fractures that preceded pegmatite emplacement. An early boron-rich vapor likely deposited the 5-10 \% concentrations of tourmaline observed in the Ptarmigan vein.

\subsection{Eu Anomaly}

Europium in apatite is controlled by coupled substitutions, so that Eu can substitute directly for $\mathrm{Ca}$ in apatite. Europium occurs as a divalent or trivalent ions. The multivalent nature of Eu allows for preferential substitution, based upon the ratio of $\mathrm{Eu}^{2+} / \mathrm{Eu}^{3+}$ in any given hydrothermal fluid. Since $\mathrm{Eu}^{3+}$ is more readily incorporated into apatite than $\mathrm{Eu}^{2+}$, a large $\mathrm{Eu}^{2+} / \mathrm{Eu}^{3+}$ ratio may manifest as a negative $\mathrm{Eu}$ anomaly, while small $\mathrm{Eu}^{2+} / \mathrm{Eu}^{3+}$ ratios may produce positive $\mathrm{Eu}$ anomalies on REE spider diagrams. This ratio of $\mathrm{Eu}^{2+} / \mathrm{Eu}^{3+}$ is controlled primarily by the initial $\mathrm{Eu}^{2+} / \mathrm{Eu}^{3+}$ ratio in the hydrothermal fluids, redox state, and temperature. In magmatic environments, the proportion of these two species is a function of oxygen fugacity. In contrast, the $\mathrm{Eu}^{2+} / \mathrm{Eu}^{3+}$ ratio in hydrothermal environments is primarily controlled by the $\mathrm{pH}$, as $\mathrm{Eu}^{3+}$ is more dominant at high $\mathrm{pH}$ conditions $(>7$ at $300{ }^{\circ} \mathrm{C}$ [53]). In general, Eu anomalies in hydrothermal systems reflect the Eu anomalies of the fluids. During the breakdown of plagioclase, $\mathrm{Eu}^{2+}$ is released along with additional REEs that were incompatible with micas [54]. Therefore, the release of $\mathrm{Eu}^{2+}$ and REEs during sericite alteration of feldspar will be incorporated into coeval apatite. The REE patterns of type -i, type - ii, and, type -iv apatite have positive Eu anomalies. The type - $\mathrm{i}$ apatite has a weak $\mathrm{Eu}$ anomaly in comparison to type - ii and type- iv apatite. The primary difference between type - ii and type - iv apatite is the relative enrichment in HREEs and a depletion in LREE in type - iv apatite. Additionally, type - iii and type $\mathrm{v}$ apatite have large negative Eu anomalies. Two potential explanations for these variations in the magnitude of the Eu anomaly is the dissolution of plagioclase or (2) an increased in $\mathrm{pH}$ or oxidation state of the mineralizing fluid. The crystallization or breakdown of feldspars alters the ratio of $\mathrm{Eu}^{2+} /$ $\mathrm{Eu}^{3+}$, thereby influencing the presence of an Eu anomaly. For example, crystallization of plagioclase prior to apatite mineralization will facilitate the uptake of $\mathrm{Eu}^{2+}$ and result in an $\mathrm{Eu}^{2+}$-depleted fluid. Furthermore, the breakdown of feldspar also releases additional Sr. Therefore, if the breakdown of plagioclase added $\mathrm{Eu}^{2+}$ to the fluid (i.e., type - ii and type - iv REE patterns), the Sr contents, when plotted against $\mathrm{Eu}$ anomalies should also be correlated. However, $\mathrm{Sr} v \mathrm{Eu} / \mathrm{Eu}^{*}$ in the apatite show a scattered distribution (Figure $8 \mathrm{f}$ ). Therefore, the enrichment in REEs from the dissolution of plagioclase was likely not responsible for the MREE depletion and positive Eu anomalies that characterize the type - iv patterns.

\subsection{Apatite Geochronolgy}

The apatite in this study likely formed coeval with early stages of sulphide precipitation. The age of the hydrothermal apatite $(2585 \pm 15 \mathrm{Ma})$ is consistent with the intrusions of the 2605 and 2590 Ma two-mica granites of the Prosperous Suite [1-2]. The near-concordant ${ }^{204} \mathrm{~Pb}$-corrected data of the LCT pegmatite-hosted apatite reveals two clusters of ages. An older near-concordant cluster with a mean concordia age $(n=4)$ of $2581 \pm 15 \mathrm{Ma}$, and a younger population with a mean Concordia age ( $\mathrm{n}$ =3) of $2519 \pm 12 \mathrm{Ma}$. Furthermore, plotting a regression through all near - concordant data for the pegmatite hosted apatite hints that metamorpic resetting occurred around 2200 Ma. 


\section{Conclusions}

The vein-hosted apatite documented in this study typically display a dark yellow core surrounded by a brighter yellow rim in cathodoluminescence. Apatite exhibits oscillatory zoning and breccia texture, which indicates that apatite precipitated from hydrothermal fluids. The apatite is petrographically indistinguishable from vein to vein. Apatite appears as an early phase that has been overprinted by later mineral phases. U-Pb dating reveals that the apatite has a crystallization age of $2590 \pm 13$ Ma.

Rare earth elements display five patterns in the hydrothermal vein-hosted apatite - (i) negative sloped pattern with minor Eu anomaly, (ii) a flat pattern with a positive Eu anomaly, (iii) a positive slope with a negative Eu anomaly, (iv) LREE depleted pattern with positive Eu anomaly, and (v) bellshaped pattern with a negative Eu anomaly. The variations in REE accompanied by changes in the abundances of other trace elements could be related to separate and distinct pulses of hydrothermal fluids with slightly different compositions. Alternatively, trace element contents of apatite reflect the chemical evolution of a single fluid through mineral precipitation and fluid-rock interaction or reflecting in situ fractionation. It is interpreted that the source of $\mathrm{U}, \mathrm{REE}, \mathrm{Y}$, as well as $\mathrm{P}$ and $\mathrm{F}$ for the studied mineralization was likely derived from melting of the Burwash sedimentary package during crustal anataxis, which then forms S-type granitic magmas that evolved to pegmatites and apatites during emplacement then volatile saturation contributing to gold mineralized quartz veins in the region.

Supplementary Materials: The following are available online at www.mdpi.com/xxx/s1, Table S1. Apatite isotopic data; Table S2. Trace element composition of apatite

Author Contributions: Conceptualization, M.R; Methodology, M.R. and C.R.M.M; Writing-Original Draft Preparation, M.W.R.; Review and Editing, C.R.M.M., D.R.L and H.F.

Funding: This project was financed in part by the Northwest Territories Geological Survey, by a grant from the New Brunswick Innovation Foundation and by the Natural Sciences and Engineering Research Council Research Council (NSERC) Discovery grants allotted to Dr. David R. Lentz.

Acknowledgments: The authors thank the many people and organizations who support this research. Brandon Boucher of UNB for their help with collecting the apatite isotope and trace element geochemistry. M.W.R wishes to thank Tim Chadwick for helpful discussions regarding the structural geology of the Ptarmigan and Tom deposits.

Conflicts of Interest: The authors declare no conflict of interest. The funders had no role in the design of the study; in the collection, analyses, or interpretation of data; in the writing of the manuscript, or in the decision to publish the results.

\section{References}

[1] Davis, W.J.; Fryers, B.J.; King, J.E. Geochemistry and evolution of Late Archean plutonism and its significance to the tectonic development of the Slave craton. Precambrian Research, 1994, 67(3-4), 207241.

[2] Davis, W.J.; Bleeker, W. Timing of plutonism, deformation, and metamorphism in the Yellowknife Domain, Slave Province, Canada. Can. J. Earth Sci. 1999, 36, 1169-1187.

[3] Kretz, R. Variation in the composition of muscovite and albite in a pegmatite dike near Yellowknife. Canadian Journal of Earth Sciences, 1970, 7(5), 1219-1235.

[4] Bleeker, W. Archaean tectonics: a review, with illustrations from the Slave craton. Geol. Soc. Lond. Spec. Publ. 2002, 199, 151-181. 
[5] Meintzer, R. E.; Cerny, P. Geological studies of rare-element pegmatites in the Yellowknife Basin of the NWT. Mineral Industry Report, Northwest Territories: INAC, NAP, Geology Division, NWT, EGS, 1985, 2, 189-202.

[6] Siegel, M. Geochemical analysis of tourmaline from the Yellowknife mining District. Unpublished MSc. Thesis, 2001, Carleton University, Ottawa, ON, Canada.

[7] Fortier, Y O. Ross Lake, Northwest Territories, Geological Survey of Canada, 1947, 47-16.

[8] Goldfarb, R.J.; Leach, D.; Pickthorn, W.J.; Paterson, C.J. Origin of lode-gold deposits of the Juneau gold belt, southeastern Alaska. Geol. 1988, 16, 440-443.

[9] Goldfarb, R.; Baker; T.; Dube, B.; Groves, D.I.; Hart, C.J.; Gosselin, P. Distribution, character and genesis of gold deposits in metamorphic terranes. Econ. Geol. 2005, 100th anniversary volume, 407-450.

[10] Pitcairn, I.K.; Teagle, D.A., Craw D.; Olivo, G.R.; Kerrich, R.; Brewer, T.S. Sources of metals and fluids in orogenic gold deposits: insights from the Otago and Alpine Schists, New Zealand. Econ. Geol. 2006, 101: 1525-1546.

[11] Mao, M.; Rukhlov, A.S.; Rowins, S.M.; Spence, J.; Coogan, L.A. Apatite trace element compositions: A robust new tool for mineral exploration. Econ. Geol. 2016, 111, 1187-1222.

[12] Henrichs, I.A.; O'Sullivan, G.; Chew, D.M.; Mark, C.; Babechuk, M.G.; McKenna, C.; and Emo, R. The trace element and U-Pb systematics of metamorphic apatite. Chem. Geol. 2018, 483: 218-238.

[13] Kirkland, C.L.; Yakymchuk, C.; Szilas, K.; Evans, N.; Hollis, J.; McDonald, B.; and Gardiner, N.J. Apatite: a U-Pb thermochronometer or geochronometer?. Litho. 2018, 318, 143-157.

[14] Bouzari, F.; Hart, J.R.H.; Bissig, T.; Barker, S. Hydrothermal Alteration Revealed by Apatite Luminescence and Chemistry: A Potential Indicator Mineral for Exploring Covered Porphyry Copper Deposits. Econ. Geol. 2016, 111, 1397-1410.

[15] Hughes, J.M.; and Rakovan, J.F. Structurally robust, chemically diverse: apatite and apatite supergroup minerals. Elements 2015, 11, 165-170.

[16] Sha, L.-K.; Chappell, B.W. Apatite chemical composition, determined by electron microprobe and laser-ablation inductively coupled plasma mass spectrometry, as a probe into granite petrogenesis. Geochim. Cosmochim. Acta 1999, 63, 3861-3881.

[17] Henrichs, I.A.; O'Sullivan, G.; Chew, D.M.; Mark, C.; Babechuk, M.G.; McKenna, C.; and Emo, R. The trace element and U-Pb systematics of metamorphic apatite. Chem. Geol. 2018, 483, 218-238. 
[18] Harlov, D.E. Apatite: A fingerprint for metasomatic processes. Elements 2015, 11, 171-176.

[19] Ayers, J. C.; Watson, E. B. Solubility of apatite, monazite, zircon, and rutile in supercritical aqueous fluids with implications for subduction zone geochemistry. Philosophical Transactions of the Royal Society of London. Phys. and Eng. Sci. 1991, 335, 365-375.

[20] Pearson, R.G. Hard and soft acids and bases. J. Amer. Chem. Soc. 1963, 85, 3533-3539.

[21] Williams-Jones, A.E.; Migdisov, A.A.; and Samson, I.M. Hydrothermal mobilisation of the rare earth elements-a tale of "ceria" and "yttria". Elements 2012, 8, 355-360.

[22] Hughes, J.M.; Ertl, A.; Bernhardt, H.J.; Rossman, G.R.; and Rakovan, J. Mn-rich fluorapatite from Austria: Crystal structure, chemical analysis, and spectroscopic investigations. Amer. Min. 2004, 89, 629-632.

[23] Miles, A.J.; Graham, C.M.; Hawkesworth, C.J.; Gillespie, M.R.; Hinton, R.W.; Bromiley, G.D. Apatite: A newredox proxy for silicic magmas? Geochim. Cosmochim. Acta 2014, 132, 101-119.

[24] Belousova, E.A.; Griffin, W.L.; O'Reilly, S.Y.; Fisher, N.I. Apatite as an indicator mineral for mineral exploration: Trace-element compositions and their relationship to host rock type. J. Geochem. Explor. 2002, 76, 45-69.

[25] Götze, J.; Schertl, H. P.; Neuser, R. D.; Kempe, U.; \& Hanchar, J. M. Optical microscopecathodoluminescence (OM-CL) imaging as a powerful tool to reveal internal textures of minerals. Miner. Petro. 2013, 107, 373-392.

[26] Bath, A.B.; Walshe, J. L.; Cloutier, J.; Verrall, M.; Cleverley, J. S.; Pownceby, M.I.; and Robinson, P. Biotite and apatite as tools for tracking pathways of oxidized fluids in the Archean East Repulse gold deposit, Australia. Econ. Geol. 2013, 108, 667-690.

[27] Chamberlain, K.R.; and Bowring, S.A. Apatite-feldspar U-Pb thermochronometer: a reliable, mid-range $\left(\sim 450^{\circ} \mathrm{C}\right)$, diffusion-controlled system. Chem. Geol. 2001, 172, 173-200.

[28] Schoene, B.; and Bowring, S.A. Determining accurate temperature-time paths from U-Pb thermochronology: An example from the Kaapvaal craton, southern Africa. Geochim. Cosmochim. Acta 2007, 71, 165-185.

[29] Cochrane, R.; Spikings, R. A.; Chew, D.; Wotzlaw, J. F.; Chiaradia, M.; Tyrrell, S.; Van der Lelij, $\mathrm{R}$. High temperature $\left(>350^{\circ} \mathrm{C}\right)$ thermochronology and mechanisms of $\mathrm{Pb}$ loss in apatite. Geochim. Cosmochim. Acta 2014, 127, 39-56. 
[30] Chew, D.M.; Sylvester, P.J.; Tubrett, M.N. U-Pb and Th-Pb dating of apatite by LA-ICPMS. Chem. Geol. 2011, 280, 200-216.

[31] Krneta, S.; Ciobanu, C.L.; Cook, N.J.; Ehrig, K.; Kontonikas-Charos, A. 2017. The Wirrda Well and Acropolis prospects Gawler Craton, South Australia: Insights into evolving fluid conditions through apatite chemistry. J. Geochem. Explor. 2017, under review.

[32] McDonough, W.F.; Sun, S.-S. Composition of the Earth. Chem. Geol. 1995, 120, 223-253.

[33] Rønsbo, J.G. Coupled substitutions involving REE's and Na and Si in apatites in alkaline rocks from Ilimaussaq, South Greenland, and the petrological implications. Am. Mineral. 1989, 74, 896-901.

[34] Pan, Y.; Fleet, M.E. Compositions of the apatite-group minerals: Substitution mechanisms and controlling factors. Rev. Mineral. Geochem. 2002, 48, 13-49.

[35] Lodders, K. Solar system abundances of the elements. In Principles and Perspectives in Cosmochemistry; Goswami, A., Reddy, B.E., Eds.; Springer Verlag: Berlin, Heidelberg, Germany, 2010; 379-417.

[36] Stacey, J.T.; Kramers, 1. Approximation of terrestrial lead isotope evolution by a two-stage model. Earth Planet. Sci. Lett. 1975, 26, 207-221.

[37] Oosthuyzen, E. J.; Burger, A.J. The suitability of apatite as an age indicator by the uranium-lead isotope method. Earth Planet. Sci. Lett. 1973, 18, 29-36.

[38] Tepper, J.H.; Kuehner, S.M. Complex zoning in apatite from the Idaho batholith: A record of magma mixing and intracrystalline trace element diffusion. Am. Miner. 1999, 84, 581-595.

[39] Barker, S.L.; Cox, S.F. Oscillatory zoning and trace element incorporation in hydrothermal minerals: insights from calcite growth experiments. Geofluids 2011, 11, 48-56.

[40] van Hees, E.H.; Sirbescu, M.L.C.; Washington, G.D.; Benda, K J.; Shelton, K.L.; Falck, H.; Trenaman, R.T. Genesis of the Ptarmigan gold deposit: Is it of magmatic affinity?. Geo. Assoc Can. Miner. Dep. Div. Spec. Publ. 2006, 3, 270-285.

[41] Garofalo, P.S.; Fricker, M.B.; Günther, D.; Bersani, D.; Lottici, P.P. Physical-chemical properties and metal budget of Au-transporting hydrothermal fluids in orogenic deposits. Geol. Soc. Lond. Spec. Publ. 2014, 402, 71-102.

[42] Raimbault, L.; Baumer, A.; Dubru, M.; Benkerrou, C., Croze, V.; Zahm, A. REE fractionation between scheelite and apatite in hydrothermal conditions. Am Miner. 1993, 78, 1275-1285. 
[43] Sylvester, P.J.; Ghaderi, M. Trace element analysis of scheelite by excimer laser ablationinductively coupled plasma-mass spectrometry (ELA-ICP-MS) using a synthetic silicate glass standard. Chem. Geol. 1997, 141, 49-65.

[44] Ghaderi, M.; Palin, J.M.; Campbell, I.H.; Sylvester, P.J. Rare earth element systematics in scheelite from hydrothermal gold deposits in the Kalgoorlie-Norseman region, Western Australia. Econ. Geol. 1999, 94, 423-437.

[45] Exley, R.A. 1980. Microprobe studies of REE-rich accessory minerals: implications for Skye granite petrogenesis and REE mobility in hydrothermal systems. Earth Planet. Sci. Lett. 1980, 48, 97110.

[46] Thorne, K.G.; Lentz, D.R.; Hall, D.C.; Yang, X. Petrology, Geochemistry, and Geochronology of the Granitic Pegmatite and Aplite Dykes Associated with the Clarence Stream Gold Deposit, Southwestern New Brunswick; Natural Resources Canada, Geological Survey of Canada: Ottawa, ON, Canada, 2002.

[47] Condie, K.C. Chemical composition and evolution of the upper continental crust: contrasting results from surface samples and shales. Chem. Geol. 1993, 104, 1-37.

[48] Goldfarb, R. J.; Groves, D. I. Orogenic gold: Common or evolving fluid and metal sources through time. Lithos 2015, 233, 2-26.

[49] Bethune, K.M.; Villeneuve, M.E.; Bleeker, W. Laser 40Ar/39Ar thermochronology of Archean rocks in Yellowknife Domain, southwestern Slave Province: insights into the cooling history of an Archean granite-greenstone terrane. Can. J. Earth Sci. 1999, 36, 1189-1206.

[50] Wright, T.L.; Okamura, R.T. Cooling and crystallization of tholeiitic basalt, 1965 Makaopuhi lava lake, Hawaii. U.S. Geol. Surv. 1977, 1004, 1-78.

[51] Humphris, S.E.; Henderson, P. The mobility of the rare earth elements in the crust. Rare Earth Elements Geochem. 1984, 2, 317-342.

[52] Kretz, R.; Hartree, R.; Jones, P. Metasomatic crystallization of muscovite in granite and tourmaline in schist related to pegmatite emplacement near Yellowknife, Canada. Contributions to Min. and Petrol, 1989, 102(2), 191-204.

[53] Brugger, J.; Etschmann, B.; Pownceby, M.; Liu, W.; Grundler, P.; Brewer, D. Oxidation state of europium in scheelite: Tracking fluid-rock interaction in gold deposits. Chem. Geol. 2008, 257, 26-33. 
[54] Adam, J.; Green, T. Trace element partitioning between mica- and amphibole-bearing garnet lherzolite and hydrous basanitic melt: 1. Experimental results and the investigation of controls on partitioning behavior. Miner. Petro. 2006, 152, 1-17. 